\title{
Truck and Rail Charges for Shipping Spent Fuel and Nuclear Waste
}
G. W. McNair
B. M. Cole
R. E. Cross
E. F. Votaw

June 1986

Prepared for the U.S. Department of Energy under Contract DE-AC06-76RLO 1830

Pacific Northwest Laboratory Operated for the U.S. Department of Energy by Battelle Memorial Institute 


\title{
DISCLAIMER
}

This report was prepared as an account of work sponsored by an agency of the United States Government. Neither the United States Government nor any agency thereof, nor any of their employees, makes any warranty, express or implied, or assumes any legal liability or responsibility for the accuracy, completeness, or usefulness of any information, apparatus, product, or process disclosed, or represents that its use would not infringe privately owned rights. Reference herein to any specific commercial product, process, or service by trade name, trademark, manufacturer, or otherwise, does not necessarily constitute or imply its endorsement, recommendation, or favoring by the United States Government or any agency thereof. The views and opinions of authors expressed herein do not necessarily state or reflect those of the United States Government or any agency thereof.

\author{
PACIFIC NORTHWEST LABORATORY \\ operated by \\ BATTELLE \\ for the \\ UNITED STATES DEPARTMENT OF ENERGY \\ under Contract DE-AC06-76RLO 1830
}

\begin{tabular}{|c|c|}
\hline \multirow{2}{*}{\multicolumn{2}{|c|}{ Printed in the United States of America }} \\
\hline & \\
\hline \multirow{2}{*}{\multicolumn{2}{|c|}{$\begin{array}{l}\text { National Technical Information Service } \\
\text { United States Department of Commerce }\end{array}$}} \\
\hline & \\
\hline \multicolumn{2}{|c|}{ S285 Port Royal Road } \\
\hline \multicolumn{2}{|c|}{ Springfield, Virginia 22161} \\
\hline \multirow{2}{*}{\multicolumn{2}{|c|}{$\begin{array}{l}\text { NIIS Price Codes } \\
\text { Microfiche A01 }\end{array}$}} \\
\hline & \\
\hline \multicolumn{2}{|c|}{ Printed Copy } \\
\hline & Price \\
\hline Pages & Codes \\
\hline 001-025 & A02 \\
\hline 026-050 & $\mathrm{A} 03$ \\
\hline 051-075 & A04 \\
\hline $076-100$ & A05 \\
\hline $101-125$ & $A 06$ \\
\hline $126-150$ & A07 \\
\hline $151-175$ & $A 08$ \\
\hline $176-200$ & $A 09$ \\
\hline $201-225$ & A010 \\
\hline $226-250$ & A011 \\
\hline $251-275$ & A012 \\
\hline $276-300$ & A 013 \\
\hline
\end{tabular}


TRUCK AND RAIL CHARGES FOR SHIPPING SPENT FUEL AND NUCLEAR WASTE

G. W. McNair

B. M. Cole

R. E. $\operatorname{Cross}(a)$

E. F. Votaw $(a)$

June 1986

Prepared for

the U.S. Department of Energy

under Contract DE-AC06-76RLD 1830

Pacific Northwest Laboratory

Richland, Washington 99352

(a) Rockwell Hanford Operations 



\section{PREFACE}

Logistics analyses supplied to the nuclear waste managenent programs of the U.S. Department of Energy (DOE) through the Transportation Technology Center (TTC) at Sandia National Laboratories are used to estimate nuclear waste materials packaging demands, shipping and receiving rates, and various transportation-related costs for alternative strategies. The reference shipping costs for various waste materials are key information used in these analyses. The Pacific Northwest Laboratory, through DnE's defense and commercial nuclear waste management programs, developed techniques that the TTC can use to estimate the costs of shipping irradiated reactor fuel (spent fuel) and nuclear waste materials. This document describes the techniques that were developed and lists representative data required when calculating estimates of the shipping cost for legal-weight truck or general-freight rail shipments of either spent fuel or nuclear waste materials. The scope of the work presented in this document is 1 imited to the costs incurred for shipping and does not include packaging or cask purchase/lease costs.

The units of weights and measures reported in this document are those currentiy used by the II.S. transportation industry. The use of these units facilitates direct use of existing transportation industry documents. 
• 


\section{ABSTRACT}

The Pacific Northwest Laboratory developed techniques for calculating estimates of nuclear-waste shipping costs and compiled a listing of representative data that facilitate incorporation of reference shipping costs into various logistics analyses. The formulas that were developed can be used to estimate costs that will be incurred for shipping spent fuel or nuclear waste by either legal-weight truck or general-freight rail.

The basic data for this study were obtained from tarrifs of a truck carrier licensed to serve the 48 contiguous states and from various rail freight tariff guides. Also, current transportation regulations as issued by the lJ.S. Department of Transportation and the Nuclear Regulatory Commission were investigated.

The costs that will be incurred for shipping spent fuel and/or nuclear waste, as addressed by the tariff guides, are based on a complex set of conditions involving the shipment origin, route, destination, weight, size, and volume and the frequency of shipments, existing competition, and the length of contracts. While the complexity of these conditions is an important factor in arriving at a "correct" cost, deregulation of the transportation industry means that costs are much more subject to negotiation and, thus, the actual fee that will be charged will not be determined until a shipping contract is actually signed. This study is designed to provide the baseline data necessary for mak ing comparisons of the estimated costs of shipping spent fuel and/or nuclear wastes by truck and rail transportation modes. The scope of the work presented in this document is limited to the costs incurred for shipping, and does not include packaging, cask purchase/lease costs, or local fees placed on shipments of radioactive materials. 


\section{SIJMMARY}

In this study the Pacific Northwest Laboratory developed techniques that can be used for estimating the costs of shipping spent fuel and/or nuclear waste. Information was collected from a truck carrier licensed to serve the 48 contiguous states and from various rail freight tariff guides. This information was the basis for developing a set of formulas that can be used to estimate Tegal-weight truck and general-freight rail shipping costs. The cost associated with shipping spent fuel and/or nuclear waste was found to depend on the following variables:

\section{LOADED PORTION OF TRIP}

TRUCK

- Distance traveled

- Weight of cask/container and contents

- Special equipment

- Escorts

- Deadhead charges (a)

- Highway route-controlled surcharges(b)

- Demurrage

- Overweight fees

RAIL

- Distance traveled

- Weight of cask/container and contents

- Escorts

$$
\begin{aligned}
& \text { UNLOADED PORTION OF TRIP } \\
& \text { (Return of Cask/Container) }
\end{aligned}
$$

TRIICK

- Distance traveled

- Weight of empty cask/container

RAIL

- Distance traveled

- Weight of empty cask/container

(a) Deadhead charges are costs incurred for moving equipment and personnel from their domicile to the shipment origin.

(b) Highway route-controlled materials are determined by their isotopic content (see Appendix B). 
In addition to the development of various cost-estimating methodologies, a series of hypothetical shipments for both spent fuel and nuclear waste were evaluated for each of the transport modes. The projected costs obtained from these hypothetical shipments allowed a comparison between the transport modes. However, the actual fee charged by a truck or rail carrier, though based on the variables listed abóve, cannot be determined until a contract is signed.

When projecting the cost for shipping spent fuel by either legal-weight truck or general-freight rail, which are routine unrestricted modes of commercial transportation, the costs for legal-weight trucks were estimated to average approximately 1.0 to 1.5 times the cost per $\mathrm{KgU}$ per one-way mile as compared to general-freight rail. The higher cost associated with shipping by truck arises from the smaller capacities of the truck shipping casks. This cost difference could be offset if slower rail transit times require the purchase or lease of many transportation casks to insure fuel movement at prescribed rates. The inclusion of costs for shipping casks is beyond the scope of this report.

The estimated cost for shipping high-level waste or transuranic (TRU) waste by general-freight rail is approximately 1.5 times greater than the cost per $\mathrm{kg}$ of waste of legal-weight truck shipments for highway route controlled (HRC) quantities of these materials and from 2 to 6 times greater than the cost per $\mathrm{kg}$ of waste for shipping non-HRC quantities.

A comparison between the cost of legal-weight truck and general-freight rail shipments for a given quantity of low-level waste is not easily obtained. Shipping low-Tevel waste by truck is currently based on a rate charged in dollars per mile rather than dollars per unit weight. The current legal-weight truck rates are based on providing carriage for a minimum of 1,500 cubic feet per truckload. This practice allows the majority of the costs for these shipments to be based on volume rather than weight. Since the rates for shipments of low-level waste by general-freight rail are based on dollars per unit weight (same rate basis used for spent fuel/high-level waste) and the majority of low-level waste shipments have a low weight-to-volume ratio, the majority of low-level waste shipments are expected to occur with legal-weight 
truck carriers. This practice is actually observed but it may be based on performance of shipment originators and end-point receivers rather than on cost considerations alone. 
• 


\section{CONTENTS}

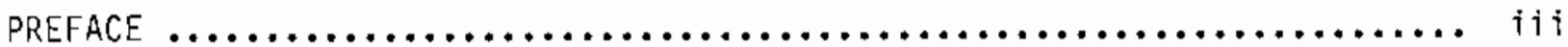

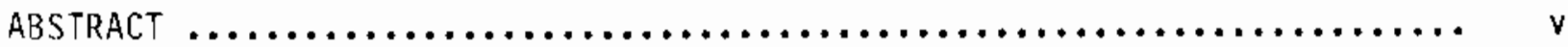

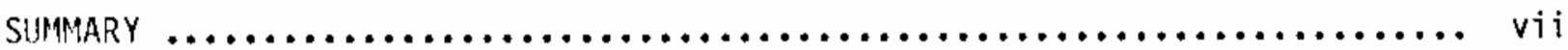

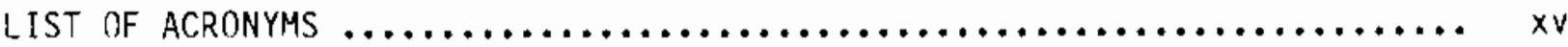

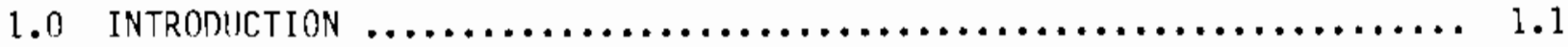

2.0 TRUCK SHIPMENTS $\ldots \ldots \ldots \ldots \ldots \ldots \ldots \ldots \ldots \ldots \ldots \ldots \ldots \ldots \ldots \ldots \ldots \ldots \ldots$

2.1 DISTANCE AND WEIGHT COSTS $\ldots \ldots \ldots \ldots \ldots \ldots \ldots \ldots \ldots \ldots \ldots \ldots \ldots \ldots$

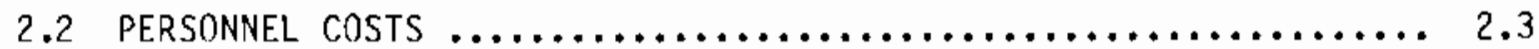

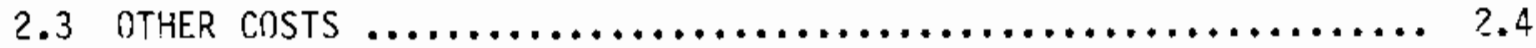

$2.4 \cdot$ SHIPPING COST CALCILATIONS $\ldots \ldots \ldots \ldots \ldots \ldots \ldots \ldots \ldots \ldots \ldots \ldots \ldots \ldots$

2.5 HYPOTHETICAL TRIJCK SHIPMENTS $\ldots \ldots \ldots \ldots \ldots \ldots \ldots \ldots \ldots \ldots \ldots \ldots \ldots . . \ldots$

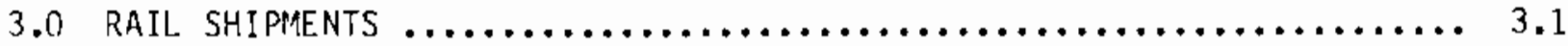

3.1 Distance and Weithit costs $\ldots \ldots \ldots \ldots \ldots \ldots \ldots \ldots \ldots \ldots \ldots \ldots \ldots \ldots \ldots \ldots \ldots$

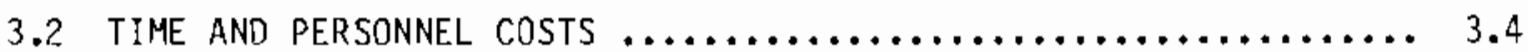

3.3 SHIPPING COST CALCIILATIONS $\ldots \ldots \ldots \ldots \ldots \ldots \ldots \ldots \ldots \ldots \ldots \ldots \ldots \ldots$

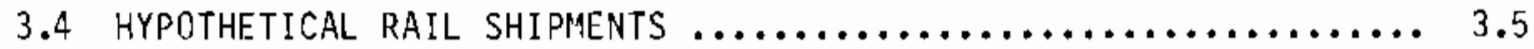

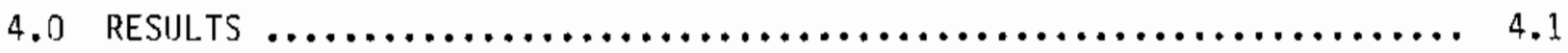

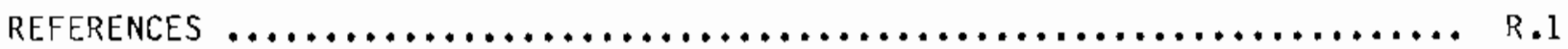

APPENDIX A--LEGAL WEIGHT TRUCK AND GENERAL FREIGHT RAIL FEE SCHEDULES .... A.1 APPENIIX B--ACTIVITY LIMITS FOR HIGHWAY ROUTE CONTROLLED NUANTITIES $\ldots . . .$. 


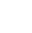




\section{FIGURES}

3.1 Regional Comparisons of General-Freight Rail Shipping Charges for Loaded Portion of Trip ................................. 3.3

3.2 Regional Comparisons of General-Freight Rail Shipping Charges for

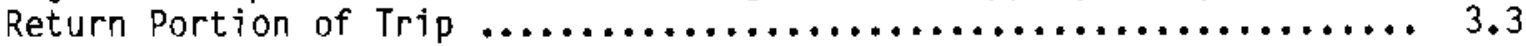

4.1 LWT and GFR Unit Shipping Cost for Spent Fuel and HRC Materials ..... 4.I

4.2 LWT and GFR Init Shipping Cost for Spent Fuel and HRC Materials .... 4.2

4.3 Shipping Cost Adders for LWT and GFR Shipments of Spent Fuel and HRC Materials ........................................ 4.3

4.4 LWT Unit Shipping Cost for NHRC Materials $\ldots \ldots \ldots \ldots \ldots \ldots \ldots \ldots \ldots \ldots 4 . \ldots$

4.5 Comparison of Shipping Cost for Spent Fuel $\ldots \ldots \ldots \ldots \ldots \ldots \ldots \ldots \ldots .4$

4.6 Comparison of Shipping Cost for High Level waste $\ldots \ldots \ldots \ldots \ldots \ldots . \ldots 4$

4.7 Comparison of Shipping Cost for Contact Handled TRI Waste ........ 4.5

4.8 Comparison of Shipping Cost for Remote Handied TRU Waste $\ldots \ldots \ldots \ldots .4 .6$ 


$\begin{array}{ll}\text { Ci } & \text { curies } \\ \text { Cwt } & \text { hundred weight (one hundred pounds) } \\ \text { DOE } & \text { Department of Energy } \\ \text { DOT } & \text { Department of Transportation } \\ \text { ft } & \text { feet } \\ \text { GFR } & \text { general-freight rail } \\ \text { GWW } & \text { gross vehicle weight } \\ \text { HRC } & \text { highway route controlled } \\ \text { Kg } & \text { kilograms } \\ \text { KgU } & \text { kilograms of uranium } \\ \text { Ib } & \text { pound } \\ \text { LWR } & \text { light water reactor } \\ \text { LWT } & \text { legal-weight truck } \\ \text { m } & \text { meter } \\ \text { NRC } & \text { Nuclear Regulatory Commission } \\ \text { NHRC } & \text { non-highway route controlled } \\ \text { TRU } & \text { transuranic } \\ \text { TTC } & \text { Transportation Technology Center }\end{array}$




\subsection{INTRODUCTION}

Basic shipping charge structures for transporting spent fuel and/or nuclear waste exist in various forms in the United States. However, the actuat fee charged by a truck or rail carrier cannot be determined under the current transportation deregulation system until an actual contract is negotiated and signed. The charge is based on a complex set of conditions involving the shipment origin, route, destination, weight, size, volume, frequency, and the existing competition and length of contract. The purpose of this report is to compile information on these charges in a manner that will provide baseline data for comparisons between the legal-weight truck and general-freight rail transportation modes. The charges listed in this report are for shipping and do not include charges that may be incurred for lease or purchase of the casks and containers required for transporting the various waste types.

This report also provides an analysis of the problems and contingencies associated with the costs of shipping various radioactive waste types. The costs of shipping radioactive wastes have changed frequentiy (sometimes monthly) during the past few years because of changes in capital, fuel, and labor costs. The costs and charges reported were derived from November 1984 data that were based on transport cask/container systems existing at that time. These reported costs and change are intended as relative cost indices only. Actual shipping costs would be negotiable for each waste type and origin/destination combination.

The methods used to estimate the truck and rail shipping costs are discussed in Chapters 2 and 3 , respectively. Descriptions of hypothetical shipments for various radioactive waste types are included in these chapters to aid readers in making comparative assessments concerning particular materials shipment. The results of comparing the estimated legal-weight truck and generalfreight rail shipping costs for hypothetical shipments of various radioactive waste types are shown in Chapter 4. 


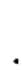




\subsection{TRUCK SHIPMENTS}

All truck shipping charges included in this report were obtajned from a single carrier (Tri-State Motor Transit Company 1984). This carrier services the 48 contiguous states in the U.S. and is capable of complying with the Nuclear Regulatory Commission (NRC) and Department of Transportation (DOT) regulations for shipping spent fuel and/or nuclear waste. The use of a single carrier provides a uniform basis for observing changes in truck shipping costs as changes in shipping concepts occur. Other carriers may use different charges.

\subsection{DISTANCE AND WEIGHT COSTS}

The basic legal-weight vehicle shipping charges used in this study for shipments of spent fuel and/or nuclear waste are, in most cases, used consistently nation-wide. Charges are primarily a function of shipment weight and distance traveled. The charges that were in use as of November 1984 are shown in Tables A.1A and A.1B of Appendix A. The charges shown in Table A.1A are used for materials that would be classified as highway route controlled (HRC) due to the activity levels of the various nuclides contained in the shipment and for non-highway route controlled materials (NHRC) that incur a gross vehicle weight in excess of 85,000 pounds $(38,556$ kilograms). Appendix B lists the activity levels required for various nuclides to be classed as HRC. Spent fuel, high-level waste, and a significant fraction of TRU shipments will be subject to these charges. Table A. BB is used for NHRC materials. The commodities shipped at NHRC-material rates would include the majority of low-level waste shipments and a portion of the TRU shipments. The rates charged for NHRC materials are expressed as dollars/mile rather than dollars/unit weight as used for KRC materials. Also, the charges for NHRC materials are broken into three categories that are based on the destination and particular type of shipping campaign employed. If the shipper uses a round-trip shipment that requires the return of empty cask/containers, the rates in Column 3 of Table A.lB would apply. If disposable packaging (requiring no return trip) is used, the rates 
would be taken from Column 1 of Table A.lB if the point of unloading is located east of the Mississippi River and Column 2 if it is located west of the Mississippi.

In addition to the mileage charges 1 isted in Tables A.1A and A.1B, the shipment may be subject to certain overweight charges imposed by various states along the route. These should not be confused with restrictions on gross vehicle weight or the special permits and procedures required for excess grossvehicle-weight shipments. These charges are listed in Table A.2. Note that the shipper is subject to overweight charges only as a function of the commodity weight, not the gross vehicle weight. Therefore, the shipper is subject to additional charge only when the comnodity shipped exceeds the weights listed in Table A.2.

The truck carrier will also charge, in addition to the charges listed in Table A.2, a fee of $\$ 0.21$ per mile for each mile traveled in states that require an overweight permit for shipments of NHRC materials in which the gross vehicle weight is less than $38,556 \mathrm{kilograms}(85,000$ pounds).

Table A.3 Tists additional charges (surcharges), that may be imposed on various shipments. If a shipment requires specially equipped vehicles and specially trained personnel, as specified by the NRC (U.S. Code of Federal Regulations 1985), an additional $\$ 0.92$ per loaded mile will be charged for legal-size and legal-weight shipments, and $\$ 1.00$ per loaded mile will be charged for overlegal-size or over-legal-weight shipments. Both charges are subject to a $\$ 200.00$ minimum per shipment. These shipments must be scheduled, in writing, at least seven days in advance. A fee of $\$ 1000.00$ will be charged if a shipment is canceled or rescheduled within the seven days. Special equipment is subject to a deadhead charge of \$2.45 per one-way mile. The mileage for this deadhead charge is computed from the nearest terminal to the point of loading.

Shipments of HRC radioactive material (excluding spent fuel) are subject to a service charge of $\$ 0.45$ per mile $(\$ 450.00$ minimum). These shipments must be scheduled, in writing, at least 10 days in advance of the pickup date and will be subject to a cancellation charge of $\$ 500.00$ if a shipment is canceled or rescheduled within seven days of the scheduled pickup date. 
When a shipment is delayed during the hours and/or days of normal travel because of any shipper-imposed or regulatory restrictions, detention penalties will be levied after the first three hours. These penalties can be as high as $\$ 32.50$ per hour (Table A.4).

\subsection{PERSONNEL COSTS}

When the carrier is required to furnish armed driver(s) or escort(s), an additional $\$ 0.20$ per mile per armed driver/escort will be assessed $(\$ 100.00$ minimum). If a separate vehicle is necessary for escort services, the fee charged is $\$ 1.48$ per mile per vehicle. This fee includes both the vehicle charge and charges for two unarmed escorts. If armed escorts are requested with the vehicle, an additional $\$ 0.20$ per mile per armed driver/escort will be assessed. The mileage for this escort vehicle is based on the distance from the domicile of the personnel and equipment to the point of origin of the shipment, then to the shipment destination, and back to the domicile point. The Code of Federal Regulations (1985) states that a vehicle transporting irradiated reactor fuel within a heavily populated area must be occupied by at least two individuals, one of whom serves as escort. The transport vehicle must also be either 1) escorted by an armed member of the local law enforcement agency or 2) led by a separate vehicle occupied by at least one armed escort and trailed by a third vehicle occupied by at least one armed escort. A transport vehicle not within any heavily populated area must be either 1) occupied by at least one driver and one other individual who serves as escort, 2) occupied by a driver and escorted by a separate vehicle occupied by at least two escorts, or 3) provided with armed escorts as required above. The requirements concerning escort services are presentiy under review by the NRC. In the Federal Register published on June 8, 1984, a proposed rulemaking by the NRC 1isted the escort requirement for spent fuel shipments (i.e., spent fuel that has cooled 150 days or more) as being only a single escort who may be a shipment vehicle operator who maintains visual surveillance of the shipment during periods when the shipment vehicle is stopped. 


\subsection{OTHER COSTS}

Many other charges can apply if any deviations occur in the original route, schedule, delivery acceptance criteria, or in-transit stops. In addition, charges may be incurred for special services or requirements requested by the shipper (e.g., security clearances). The Code of Federal Regulations does not reference security clearance requirements for drivers or escorts. However, if clearances are required or requested, the following additional charges will be applicable:

Secret or "L" cleared driver - \$0.12 per mile

"Q" cleared driver - \$0.15 per mile

Two "Q" cleared drivers - \$0.15 per mile per driver plus \$200.

\subsection{SHIPPING COST CALCILLATIONS}

The cost to transport spent fuel and/or nuclear waste by truck between two locations can be approximated by using the following formula:

$$
\begin{aligned}
\text { Shipping cost }= & (A A * L O A D)+(A B * E M P T)+(D H C * D I S 2)+(S V C * D I S 3) \\
& +(A E C * D I S 4)+(S E C * D I S 1)+D W C+D E T+(H R C * D I S 1)
\end{aligned}
$$

where

$$
A A=V a l u e \text { from table } A \cdot 1 A\left[C o l u m n ~ 1\left(\$ / \text { cwt }^{(a)}\right)\right] \text {, or Table } A .1 B
$$

[Column 1, 2, or $3(\$ / m i l e)]$ for specified distance traveled with a full cask/container

$A B=$ value from Table $A .1 A[$ Column 2. (\$/Cwt)], or Table $A .1 B$ [Column 1,2 , or $3(\$ / m i l e)]$ for specified distance traveled with an empty cask/container

$\mathrm{AEC}=$ Charge for each armed escort, $\$ 0.20 /$ man-mile (if required) DET = Personnel and equipment detention charge, dollars DHC = Deadhead charge for special equipment, $\$ 2.45 / \mathrm{mile}$ (if required)

(a) cwt $=$ hundred weight $(100$ pounds $)$. 


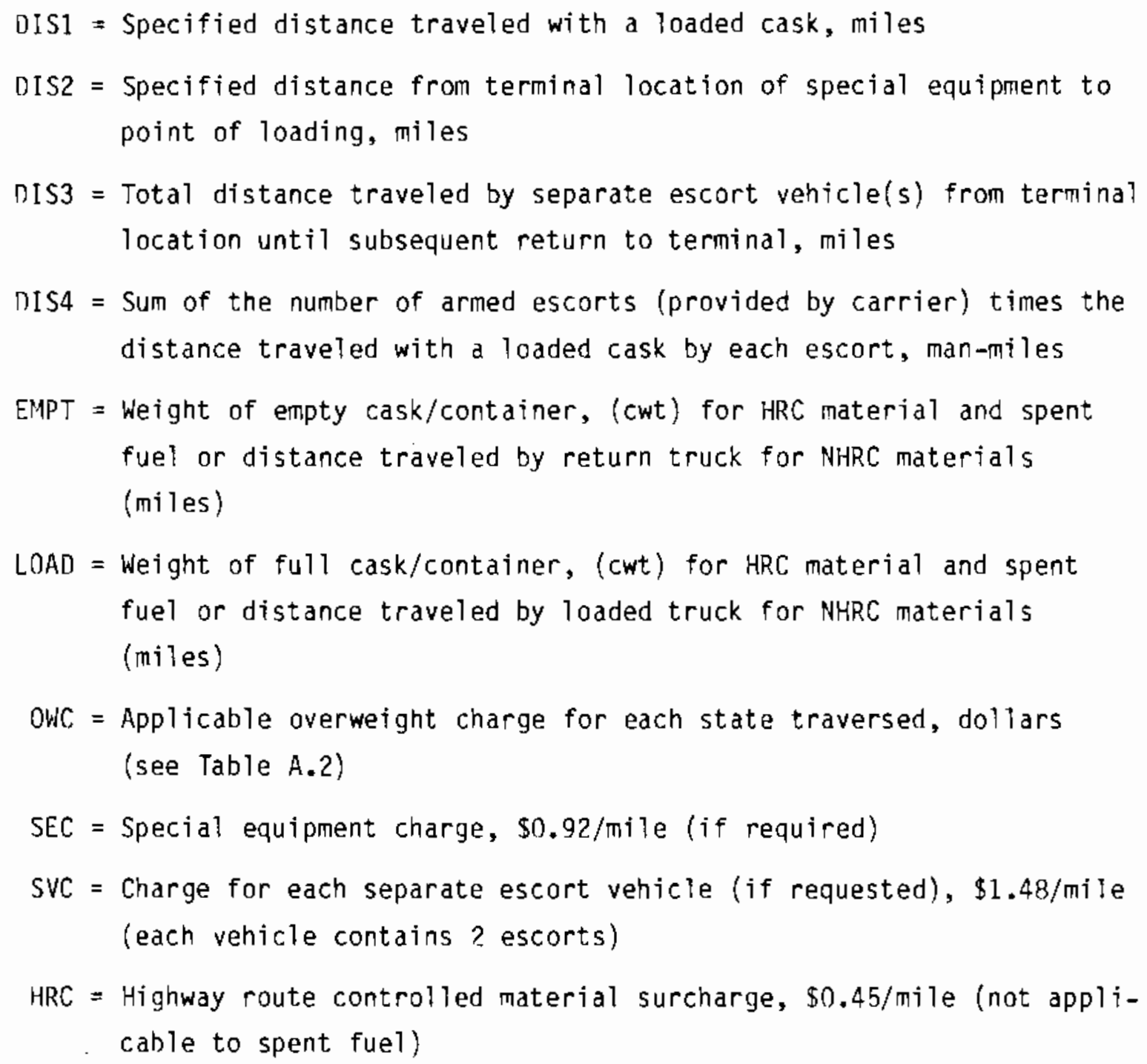

\subsection{HYPOTHETICAL TRUCK SHIPMENTS}

The use of the above formula may be demonstrated by considering the following 1200-mile hypothetical truck shipments for spent fuel and various classes of nuclear waste.

\section{Spent Fuel}

In this example, a spent-fuel shipment is postulated to be part of a longterm shipping campaign requiring frequent shipments. The constant utilization of both equipment and personnel allows the neglect of applicable deadhead charges. One armed escort is assumed to be required during the loaded segment 
of the trip and will ride in the truck cab. If the route passes through a heavily populated area, a separate escort vehicle will also be required. It is assumed that this service will be provided at no additional cost by a local law enforcement agency.

Using a loaded cask weight of 50,000 pounds $(22,680$ kilograms) and an empty cask weight of 48,650 pounds (2,068 kilograms) (see Table A.5), the cost per round trip is calculated using the formula described on page ?.4.

$$
\begin{aligned}
&(A A * \text { Load })=(6.03 * 500)=\$ 3015.00 \\
&(A B * E M P T)=(5.05 * 486.50)=2456.83 \\
&(A E C * 0 I S 4)=(0.20 * 1200)= 240.00 \\
&(S E C * D I S 1)=(0.92 * 1200)=\frac{1140.00}{} \\
& \text { Total Estimated Shipping Costs }=\$ 6815.83
\end{aligned}
$$

For this hypothetical case, the terms of the formula have the following values.

$$
\begin{aligned}
& A A=\$ 6.03 / \text { cwt }(\text { Table A.1A, Column 1) } \\
& \text { LOAD }=500 \mathrm{cwt}(50,000 / 100) \\
& A B=\$ 5.05 / \mathrm{cwt}(\text { Table A.1A, Column 2) } \\
& \text { EMPT }=486.5 \mathrm{cwt}(48,650 / 100) \\
& A E C=\$ 0.20 / \text { man-mile } \\
& \text { OIS4 }=1200 \text { man-miles } \\
& \text { DIS1 }=1200 \text { loaded miles } \\
& \text { SEC }=\$ 0.92 / \text { loaded mile } \\
& \text { Remaining variables }=0
\end{aligned}
$$

Based on a uranium weight of 904 pounds (410 kilograms), the unit cost of this hypothetical shipment is approximately $\$ 7.54$ per pound $\mathrm{U}(\$ 16.62$ per kilogram U). This cost could increase if the separate escort vehicle was not supplied free of charge by a local law enforcement agency or if the shipping campaign was non-routine and required the inclusion of deadhead charges. Conversely, the cost could possibly decrease through the negotiation of a longterm contract involving frequent shipments. 
HRC Materials

In this hypothetical case the shipment is postulated to contain remotehandled TRU waste containing HRC quantities of various nuclides. A loaded-cask weight of 50,000 pounds $(22,680$ kilograms $)$ and an empty-cask weight of 40,000 pounds $(18,141$ kilograms) (see Table A.5) results in the following trip cost.

$$
\begin{aligned}
(A A * L O A D) & =(6.03 * 500)=\$ 3015.00 \\
(A B * E M P T) & =(5.05 * 400)=2020.00 \\
(H R C * D I S 1) & =(0.45 * 1200)=\frac{540.00}{} \\
\text { Total Estimated Shipping Costs } & =\$ 5575.00
\end{aligned}
$$

The applicable terms of the formula have the following values.

$$
\begin{aligned}
& A A=\$ 6.03 / \mathrm{cwt}(\text { Table } A .1 \mathrm{~A}, \text { column } 1) \\
& \text { LOAD }=500 \mathrm{cwt}(50,000 / 100) \\
& A B=\$ 5.05 / \mathrm{cwt}(\text { Table } \mathrm{A} .1 \mathrm{~A}, \text { Column } 2) \\
& \text { EMPT }=400 \mathrm{cwt}(40,000 / 100) \\
& H R C=\$ 0.45 / \text { loaded mile } \\
& \text { OIS1 }=1200 \text { loaded miles } \\
& \text { Remaining variables }=0
\end{aligned}
$$

Based on a waste weight (waste plus containers) of 10,000 pounds (4356 kilograms), the unit cost of this hypothetical shipment is approximately $\$ 0.56$ per pound waste (\$1.23 per kilogram waste). As in the previous case, this cost could possibly decrease through the negotiation of a long-term contract involving frequent shipments.

NHRC Materials

This shipment is postulated to contain non-shielded, low-level waste packaged in disposable containers, with a final destination located west of the Mississippi river. The total cost for this trip, where only two terms of the formula are used, may be calculated as follows:

Total Estimated Shipping Cost $=(A A \star L O A D)=(1.90 \star 1200)=\$ 2280.00$ 
The values for the two required terms are:

$$
\begin{aligned}
A A & =\$ 1.90 / \text { mile }(\text { Table A.1B, Column 2) } \\
\text { LOAD } & =1200 \text { miles }
\end{aligned}
$$

Remaining variables $=0$

Based on a volume of approximately 530 cubic feet (15 cubic meters) per truckload of unshielded, low-level waste, the unit cost of this shipment is $\$ 4.30$ per cubic foot waste $(\$ 152.00$ per cubic meter waste).

If the waste for this hypothetical shipment requires shieiding, then the return of the shielded cask must also be accounted for as follows.

$$
\begin{aligned}
& (A A * L O A D)=(1.42 * 1200)=\$ 1704.00 \\
& (A B * E M P T)=(1.42 * 1200)=\frac{1704.00}{\text { Total Estimated Shipping Cost }=\$ 3408.00}
\end{aligned}
$$

The following values are assigned to the applicable terms in this case.

$$
\begin{aligned}
& A A=\$ 1.42 / \text { mile (Table A. } 1 B, \text { Column } 3) \\
& A B=\$ 1.42 / \text { mile (Table A.1B, Column 3) } \\
& \text { LOAD }=1200 \text { miles } \\
& \text { EMPT }=1200 \text { miles } \\
& \text { Remaining variables }=0
\end{aligned}
$$

Based on an assumed volume of 159 cubic feet (4.5 cubic meters) per truckload of shielded low-level waste, the unit cost now becomes $\$ 21.43$ per cubic foot waste $(\$ 757.33$ per cubic meter waste). 


\subsection{RAIL SHIPMENTS}

Determining rail shipping costs is not as straightforward as determining costs for shipments by truck. Rail charges are not uniformly applied over the distance traveled. Rail shipping costs can be affected by topography, state regulations, the number of carriers servicing the same origin/destination, and the route used. Therefore, to establish uniformity in this study, interregional rates were used.

\subsection{DISTANCE AND WEIGHT COSTS}

To obtain a reasonable and useful set of charges for spent fuel and/or nuclear waste shipped by rail, the U.S. was divided into four regions. This division was used to isolate any major cost differences that may exist. Fifty-eight light water reactor (LWR) locations (only those having reactors currently operating or under construction and with rail service available) were used as potential shipment origins. Five hypothetical sites were used as destinations. One location in each region was used to simulate regional differences (see Table 3.1), and one location was designated as a national site to simulate transcontinental shipments. Table 3.1 shows which states would ship to each of these final destinations. It should be emphasized that only hypothetical sites were used in this study to establish comparative point-to-point shipping charges.

The rail charges established are for generai-freight service of radioactive materials including spent fuel and nuclear waste (Traffic Executive Association--Eastern 1982). Tables A.6 through A.10 list these charges, the reactors serviced, and the location of the closest town used to establish these charges. These tables also show the short-line distances(a) and the approximate transit times. In some cases, especially in long hauls, the distances and charges quoted may be the same for two different points of origin, although these points can actually be only a few miles apart. These identical charges

\footnotetext{
(a) Short-line distance is defined as the shortest rail route between two rate-basing areas.
} 
TABL.F. 3.1. Assumed Origins and Destination

\begin{tabular}{|c|c|c|c|}
\hline \multicolumn{2}{|r|}{ Destination } & \multicolumn{2}{|c|}{$\begin{array}{l}\text { States from which } \\
\text { Shipments Originate (a) }\end{array}$} \\
\hline & National & Al & States \\
\hline 2. & Western & $\begin{array}{l}\text { Washington } \\
\text { CoTorado } \\
\text { Oregon }\end{array}$ & $\begin{array}{l}\text { California } \\
\text { Arizona }\end{array}$ \\
\hline 3. & Southern & $\begin{array}{l}\text { Texas } \\
\text { Arkansas } \\
\text { Florida } \\
\text { Georgia } \\
\text { Kansas } \\
\text { Louisiana }\end{array}$ & $\begin{array}{l}\text { Alabama } \\
\text { Mississippi } \\
\text { Tennessee } \\
\text { South Carolina } \\
\text { North Carolina } \\
\text { Virginia }\end{array}$ \\
\hline & North Central & $\begin{array}{l}\text { Illinois } \\
\text { Minnesota } \\
\text { Nebraska }\end{array}$ & $\begin{array}{l}\text { Iowa } \\
\text { Missouri } \\
\text { Wisconsin }\end{array}$ \\
\hline & Northeastern & $\begin{array}{l}\text { Indiana } \\
\text { Maine } \\
\text { Maryland } \\
\text { Michigan } \\
\text { New York } \\
\text { Ohio }\end{array}$ & $\begin{array}{l}\text { Connecticut } \\
\text { Massachusetts } \\
\text { New Hampshire } \\
\text { New Jersey } \\
\text { Pennsylvania } \\
\text { Vermont }\end{array}$ \\
\hline
\end{tabular}

(a) States not shown have no reactors with rail service.

can occur because both points of origin lie in the same rate-basing area. (a) Shipping charges are established between rate-basing areas regardless of the actual route traveled. The rail transit times are difficult to define with any degree of certainty because too many variables are involved in any origindestination combination to obtain a precise value. The times quoted in Tables A. 6 through $A .10$ are based on past experience for the areas and/or routes involved.

The charges for general-freight service for radioactive materials are very uniform when based on the short-line distances. Only minor variations are evident between regions (see Figures 3.1 and 3.2 ). The Western region appears to

(a) Rate-basing areas are areas around major rail points that are grouped together for rate-making purposes. 


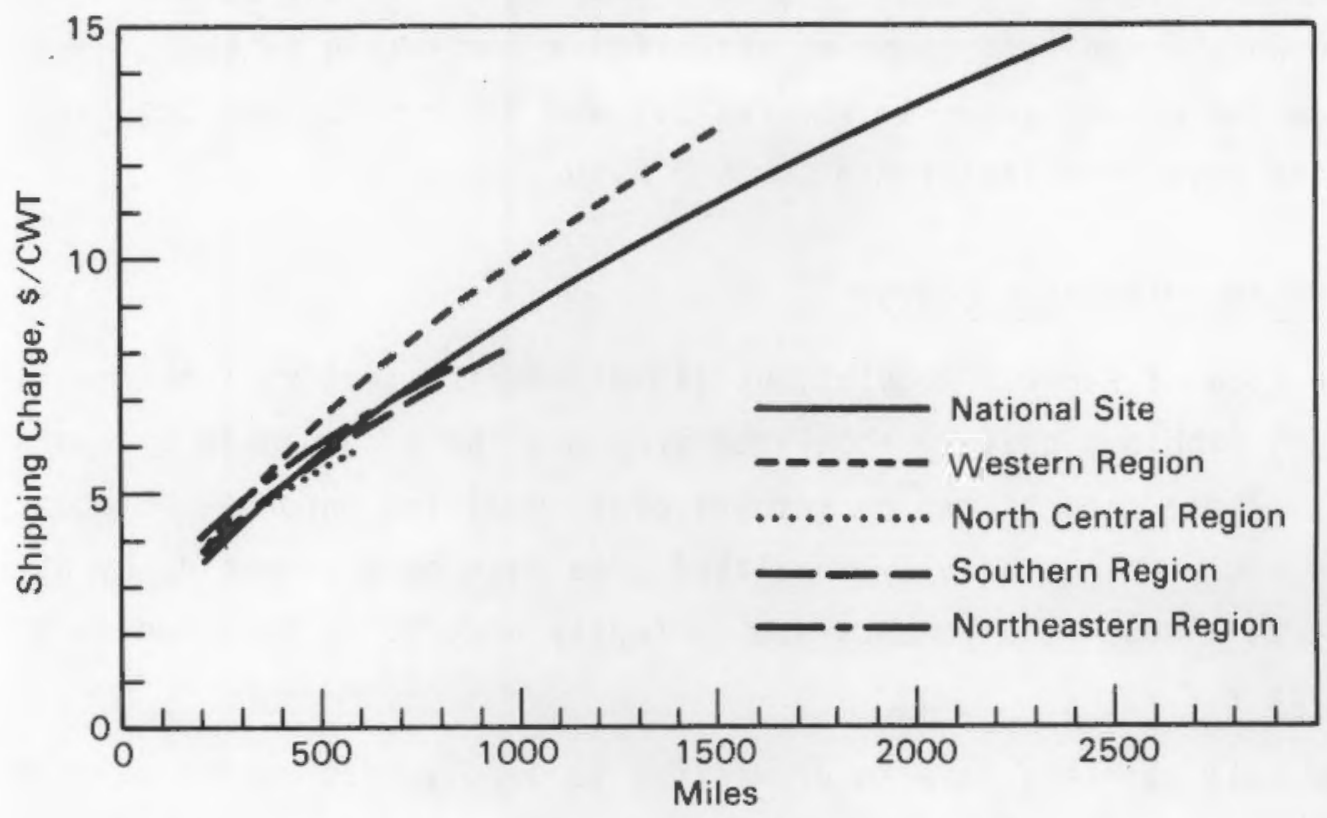

FIGURE 3.1. Regional Comparisons of General-Freight Rail Shipping Charges for Loaded Portion of Trip

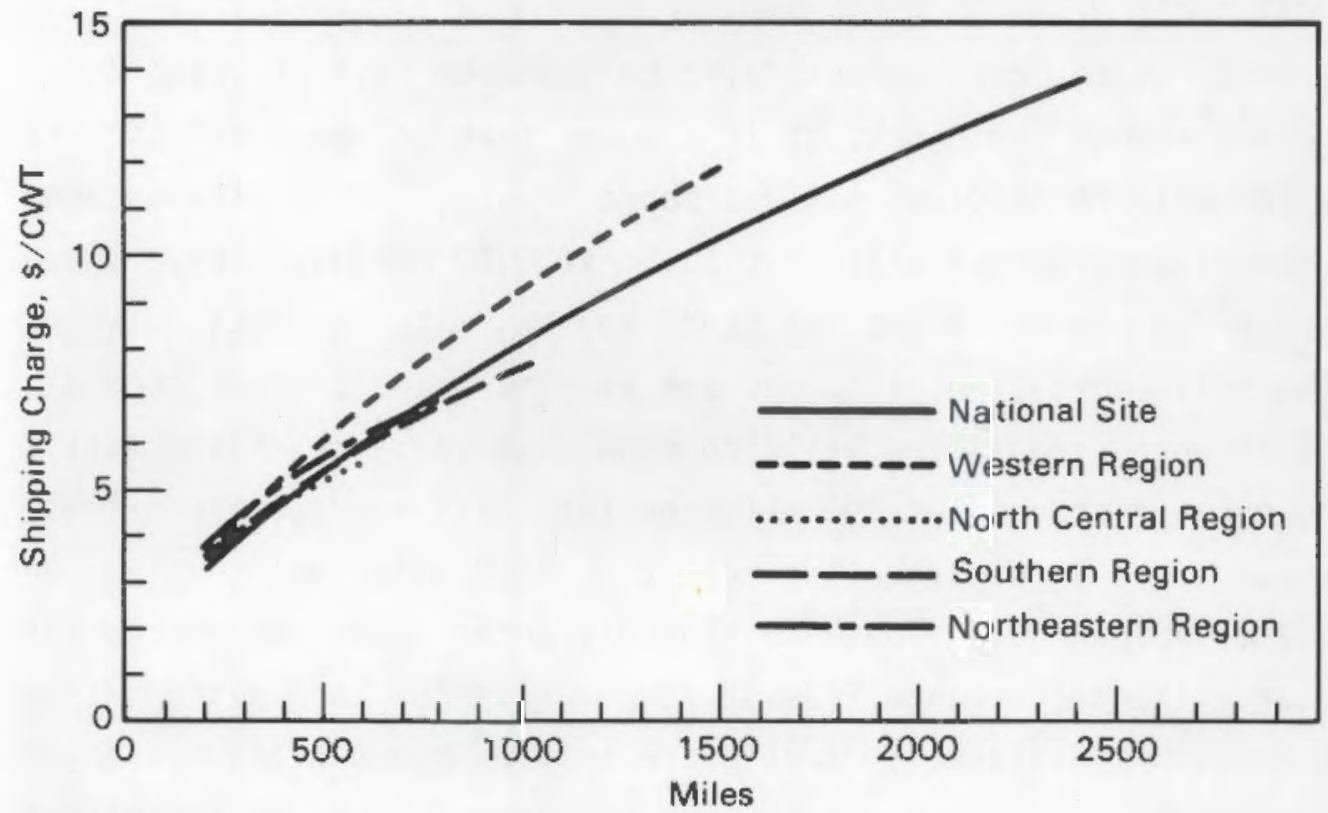

FIGURE 3.2. Regional Comparisons of General-Freight Rail Shipping Charges for Return Portion of Trip 
have somewhat higher charges. However, the number of data points available for this region are not sufficient to establish a conclusive pattern. The values that form the curves shown in Figures 3.1 and 3.2 result from regression analysis of the data from Tables A.6 through A.10.

\subsection{TIME AND PERSONNEL COSTS}

The Code of Federal Regulations (1985) require that rail shipments of spent fuel within a heavily populated area must be accompanied by two armed escorts. These escorts may be members of a local law enforcement agency. A shipment not within a heavily populated area must be accompanied by at least one escort. These requirements are currently undergoing revision as discussed in Section 2.2.

The rail carriers have no provisions to supply this escort service, which typically is expected to be provided by the shipper. However, the rail carriers will supply a car or caboose for the escorts. The only charge for this service is the price of a coach-class passenger ticket. This charge is approximately $\$ 0.08$ per mile per escort.

The wages of the escorts must also be added to rail shipping costs. Since trains travel around the clock, it is assumed that at least two escorts will be required per trip to provide constant surveillance. It is also assumed that trained security personnel will cost about $\$ 250.00$ per day each. The distance that a train can travel in one day tends to vary with the total distance traveled. The rail short-line distances and average transit times from Tables A. 6 through A.10 were used as the basis to show this variance (Table A.11). Trains traveling total distances of 300 miles or less will average approximately 47 miles per day. Those traveling more than 1900 miles will average approximately 182 miles per day. These average distances cause the charge for continuous surveillance to range from $\$ 2.75$ per mile for long distances to $\$ 10.64$ per mile for short distances. Adding the cost of coach-class passenger ticket causes the total cost for escort service to range from $\$ 2.91$ per mile to $\$ 10.80$ per mile. 


\subsection{SHIPPING COST CALCULATIONS}

The cost to ship radioactive materials from point to point by generalfreight rail can be approximated using the following formula:

Shipping Cost $=(C V L *$ LOAD $/ 100)+($ CVE * EMPT/100 $)+(E S F G F * D I S 1)$

where

$$
\begin{aligned}
& \text { CVL }=\text { Loaded cask/container shipping cost approximation, \$/cwt } \\
& =0.1616 * D I S 10.5860 \text { (National) } \\
& =0.1565 * 0 \text { IS1 }^{0.6087} \text { (Western) } \\
& =0.4025 * D I S 10.4304 \text { (North Central) } \\
& =0.2639 * D I \$ 10.5042 \text { (Southern) } \\
& =0.3969 * D I S 1^{0.4469} \text { (Northeastern) } \\
& \text { CVE = Empty cask/container shipping cost approximation, \$/Cwt } \\
& =0.1479 * 01 S 20.5895 \text { (Nationa 1) } \\
& =0.1477 * \text { DIS2 } 0.6077 \text { (Western) } \\
& =0.3796 * D I S 20.4292 \text { (North Central) } \\
& =0.2472 * \text { DIS2 } 0.5042 \text { (Southern) } \\
& =0.3727 * D I S 2^{0.4468} \text { (Northeastern) }
\end{aligned}
$$

\subsection{HYPOTHETICAL RAIL SHIPMENTS}

The use of the above formula may be demonstrated by considering the following 1200-mile hypothetical rail shipments for spent fuel and radioactive material.

Spent Fuel

For baseline comparison purposes, the parameters detailing the hypothetical rail shipment will remain consistent with those used in Section 2.5 
describing truck shipments. The shipment by rail will utilize two escorts riding on the train to maintain a 24-hour surveillance. Having two escorts present will also satisfy the present security requirement while traveling through heavily populated areas. The cost for this service is assumed to be $\$ 3.66$ per mile (see Section 3.2).

Applying the formula shown on page 3.5 , which was developed from the national average rail cost curve shown in Section 3.1 , the roundtrip shipping cost is calculated as follows.

The terms of the formula have the following values.

$$
\begin{aligned}
\text { CVL } & =0.1616 * \text { DIS1 }^{0.5860} \\
\text { LOAD } & =180,000 \text { pounds } \\
\text { CVE } & =0.1479 * \text { DIS2 }{ }^{0.5895} \\
\text { EMPT } & =169,300 \text { pounds } \\
\text { ESFGF } & =\$ 3.66 / 1 \text { oaded mile } \\
\text { DIS1 } & =1200 \text { miles } \\
\text { DIS2 } & =1200 \text { miles }
\end{aligned}
$$

The formula is then used to calculate shipping cost.

$$
\begin{aligned}
& \text { Shipping Cost }=\left(0.1616 * 1200^{0.5860}\right) * 180,000 / 100=\$ 18,540.19 \\
& +\left(0.1479 * 1200^{0.5895}\right) * 169,300 / 100=16,360.72 \\
& +3.66 * 1200=4,392.00
\end{aligned}
$$

Based on a uranium weight of 7180 pounds ( $3256 \mathrm{kilograms),} \mathrm{the} \mathrm{unit} \mathrm{cost} \mathrm{for}$ this hypothetical rail shipment is $\$ 5.47$ per pound U ( $\$ 12.07$ per kilogram U). This unit cost is lower than the comparable cost calculated for a shipment by truck (\$7.54 per pound 1), Section 2.5, page 2.6). The comparison of these costs is for shipping only. The charges for leasing or purchasing casks have not been included.

As noted in the previous chapter, the shipping cost could increase if the assumed escort requirements were not adequate. Also, negotiation of a longterm contract could possibly result in a decrease in shipment cost. 
Nuclear Waste

Shipment costs involving all classes of nuclear waste may be estimated in a manner almost identical to that used for spent-fuel shipments, the only difference being that the security cost imposed for spent fuel shipments can be neglected. The projected shipping cost for shipping a hypothetical shipment of RH-TRU waste by general-freight rail is calculated as follows.

The terms of the formula have the following values.

$$
\begin{aligned}
\text { CVL } & =0.1616 * \text { DIS1 } 1^{0.5860} \\
\text { LOAD } & =200,000 \text { pounds } \\
\text { CVE } & =0.1479 \star \text { DIS2 }{ }^{0.5895} \\
\text { EMPT } & =160,000 \text { pounds } \\
\text { DIS1 } & =1200 \text { miles } \\
\text { DIS2 } & =1200 \text { miles } \\
\text { ESFGF } & =0
\end{aligned}
$$

Using the formula again, the shipping cost is calculated

$$
\begin{aligned}
\text { Shipping Cost }= & \left(0.1616 * 1200^{0.5860}\right) * 200,000 / 100=\$ 20,600.21 \\
& +\left(0.1479 * 1200^{0.5895}\right) * 160,000 / 100=\frac{15,461.99}{~ T o t a l ~ E s t i m a t e d ~ S h i p p i n g ~ C o s t ~}=\$ 36,062.20
\end{aligned}
$$

Based on a waste weight (waste plus containers) of 40,000 pound $(18,141 \mathrm{kilo-}$ grams), the unit cost of this hypothetical shipment is approximately $\$ 0.90$ per pound waste ( $\$ 1.99$ per kilogram waste). This unit cost is higher than the comparable cost calculated for a shipment by truck ( $\$ 0.56$ per pound waste, Section 2.5, page 2.7). 


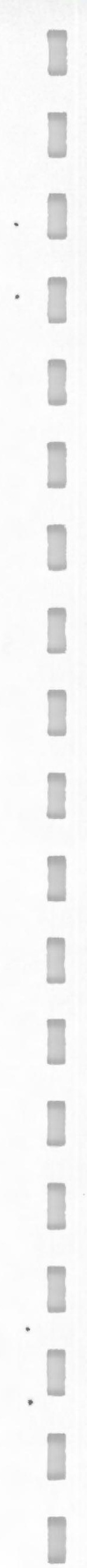




\subsection{RESULTS}

By utilizing the formulas developed for legal-weight truck and generalfreight rail shipments of spent fuel and/or radioactive waste, a series of curves (Figures 4.1 through 4.4) were generated showing unit cost comparisons between estimated shipping costs for each of these modes of transport for various radioactive waste materials at various distances. The basic shipping cost curves for HRC materials are shown for one-way mileages from 0 to 1000 miles and from 1000 to $3000 \mathrm{miles}$. The adders (surcharge) curves are projections of the costs that may be incurred to meet safeguards and security requirements. The curves shown for non-HRC materials represent the costs that will be incurred for shipments to various destination locations.

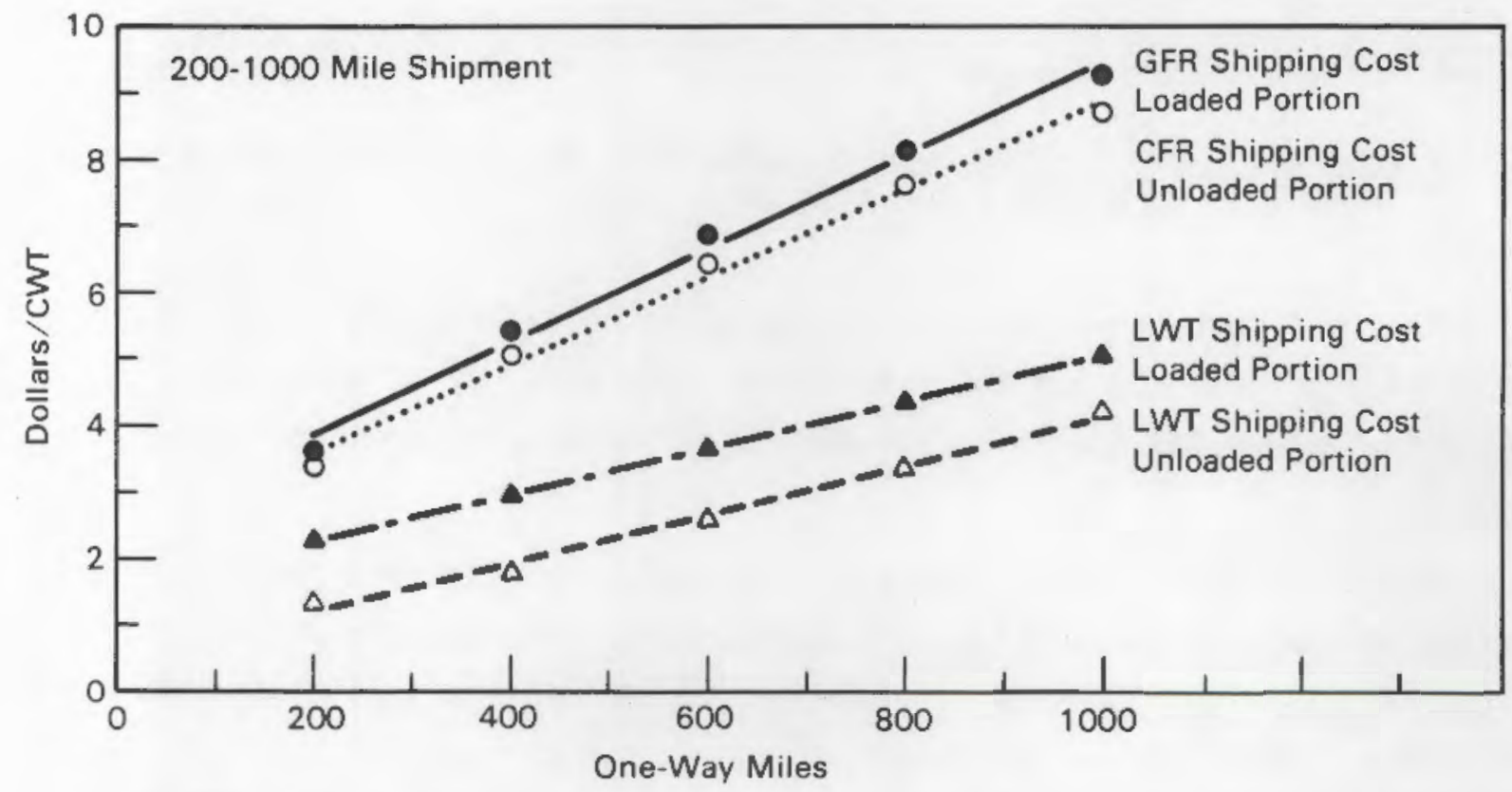

LWT $=$ Legal Weight Truck

GFR $=$ General Freight Rail

HRC = Highway Route Controlled

FIGURE 4.1. LWT and GFR Unit Shipping Cost for Spent. Fuel and HRC Materials (0-1000 miles) 


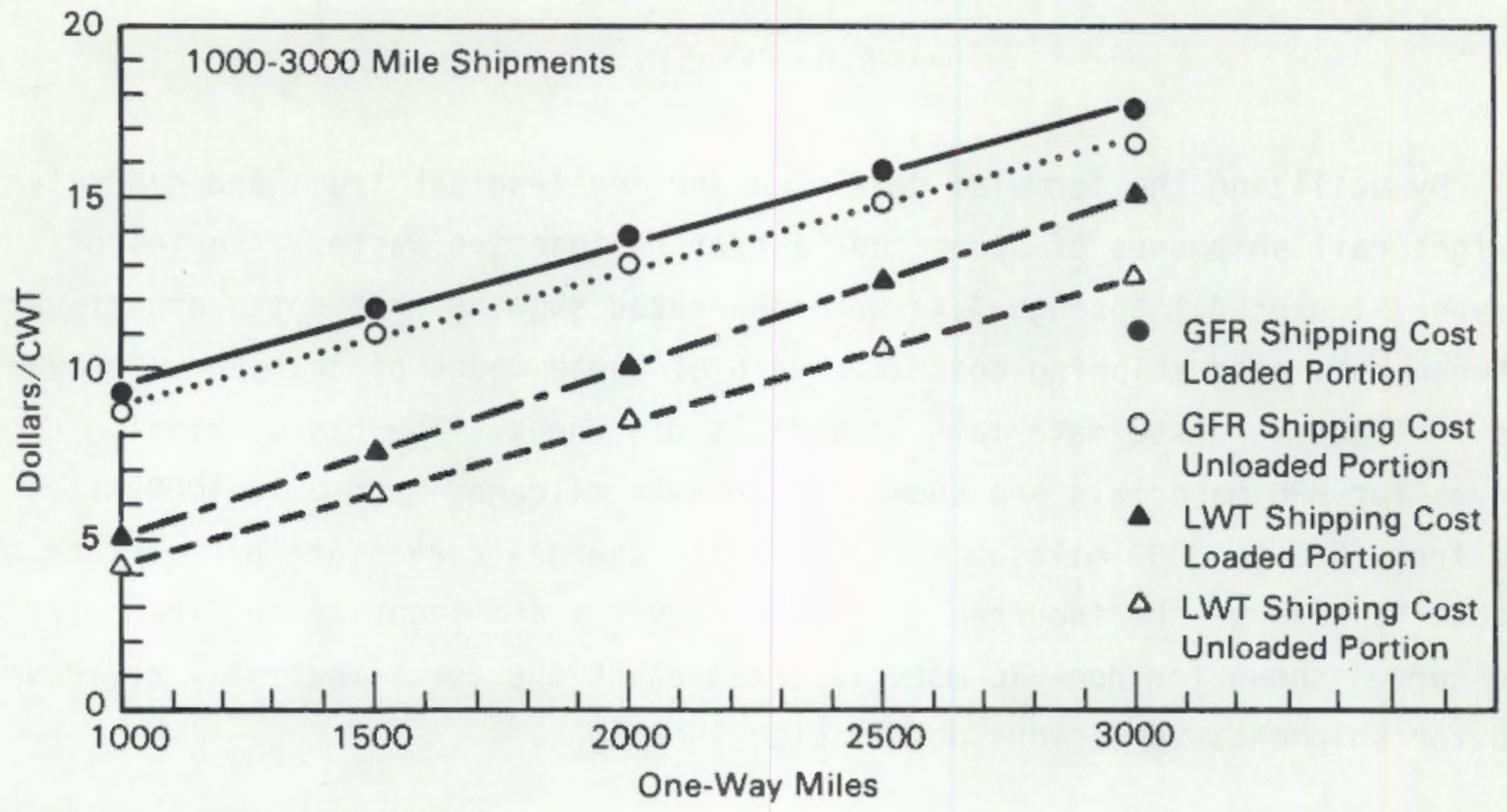

LWT $=$ Legal Weight Truck

GFR $=$ General Freight Rail

HRC $=$ Highway Route Controlled

FIGURE 4.2. LWT and GFR Unit Shipping Cost for Spent Fuel and HRC Materials (1000-3000 miles)

The unit cost curves may be used by assuming cask/packaging weights and capacities to generate projected shipping costs that may be incurred. Representative values for specific cask and commodity weights are provided in Table A.5.

Utilizing the specific weight and commodity descriptions from Table A.5, a series of comparative shipping cost curves were generated for shipments by either legal-weight truck or general-freight rail for various radioactive waste materials. These curves are shown in Figures 4.5 through 4.8 . It is important to note that these curves are representative of the specific cask/packaging specifications listed in Table A.5. The curves will vary if a different cask/ packaging is specified.

The unit cost (\$ per $k g i j)$ for shipping spent fuel assemblies as a function of miles is shown in Figure 4.5. The legal-weight truck curve utilizes the minimum security charge shown in Figure 4.3. This charge is incurred for 


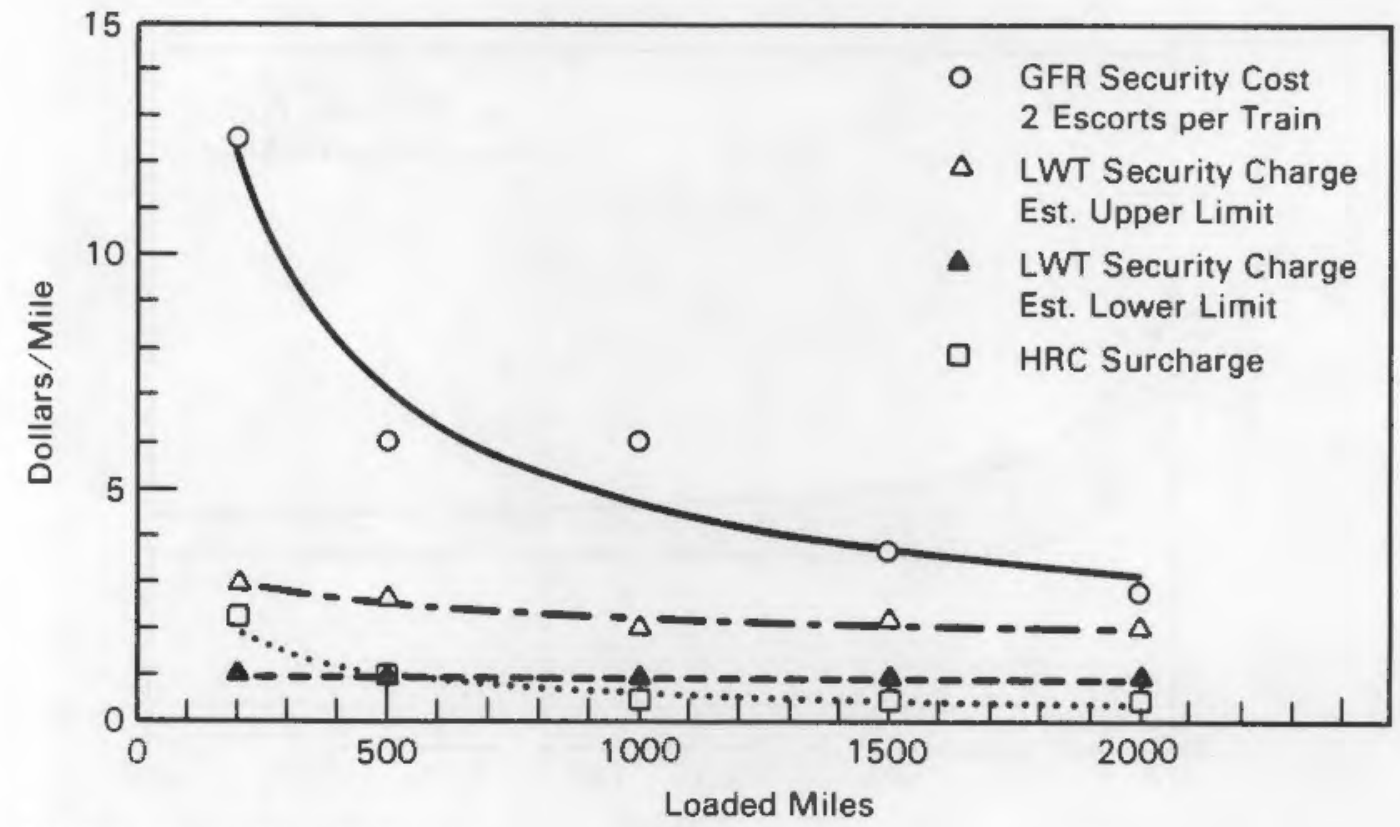

LWT $=$ Legal Weight Truck

GFR $=$ General Freight Rail

$\mathrm{HRC}=$ Highway Route Controlled

\section{FIGURE 4.3. Shipping Cost Adders (Surcharges) for LWT and} GFR Shipments of Spent Fuel and HRC Materials

providing special equipment required for safeguards and security. The generalfreight rail curve includes additional charges for armed escorts as shown in Figure 4.3. This figure shows the unit costs for shipping by legal-weight truck to be about 1.0 to 1.5 times greater than that for general-freight rail. These data can be misleading because they represent only one part of the overall cost of transporting spent fuel. The overall cost of transporting spent fuel must also include the cost to purchase or lease shipping casks and the number of casks necessary to handle a prescribed volume. Conceivably, the slow transit speed for rail shipments could cause higher cask lease rates and, therefore, could increase the overall transportation cost by rail. That aspect of the shipping costs was not analyzed in this report.

The comparison of the unit cost for shipping high-level radioactive waste or TRU waste by either legal-weight truck or general-freight rail is shown in Figures 4.6, 4.7, and 4.8. The estimated costs for shipping these commodities by general-freight rail is shown to be approximately 1.5 times the cost of 


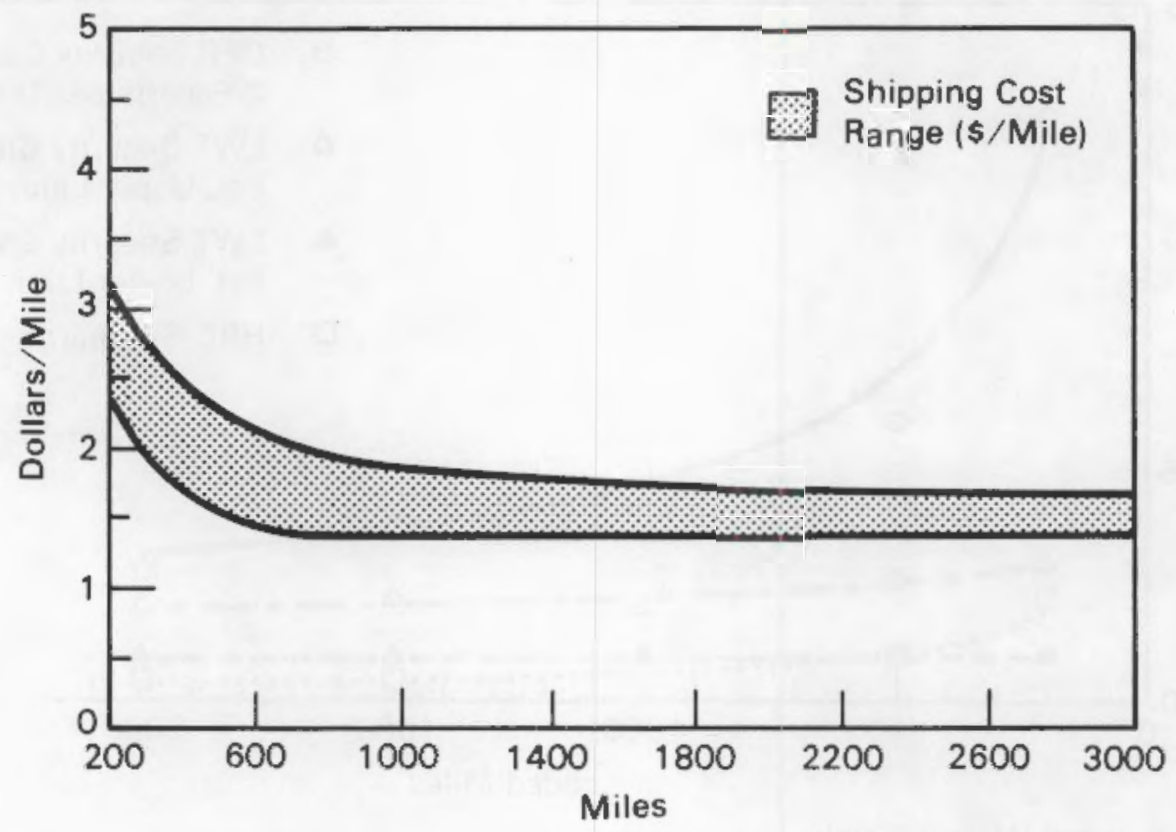

LWT $=$ Legal Weight Truck

NHRC $=$ Non-Highway Route Controlled

FIGURE 4.4. LWT Unit Shipping Cost for NHRC Materials

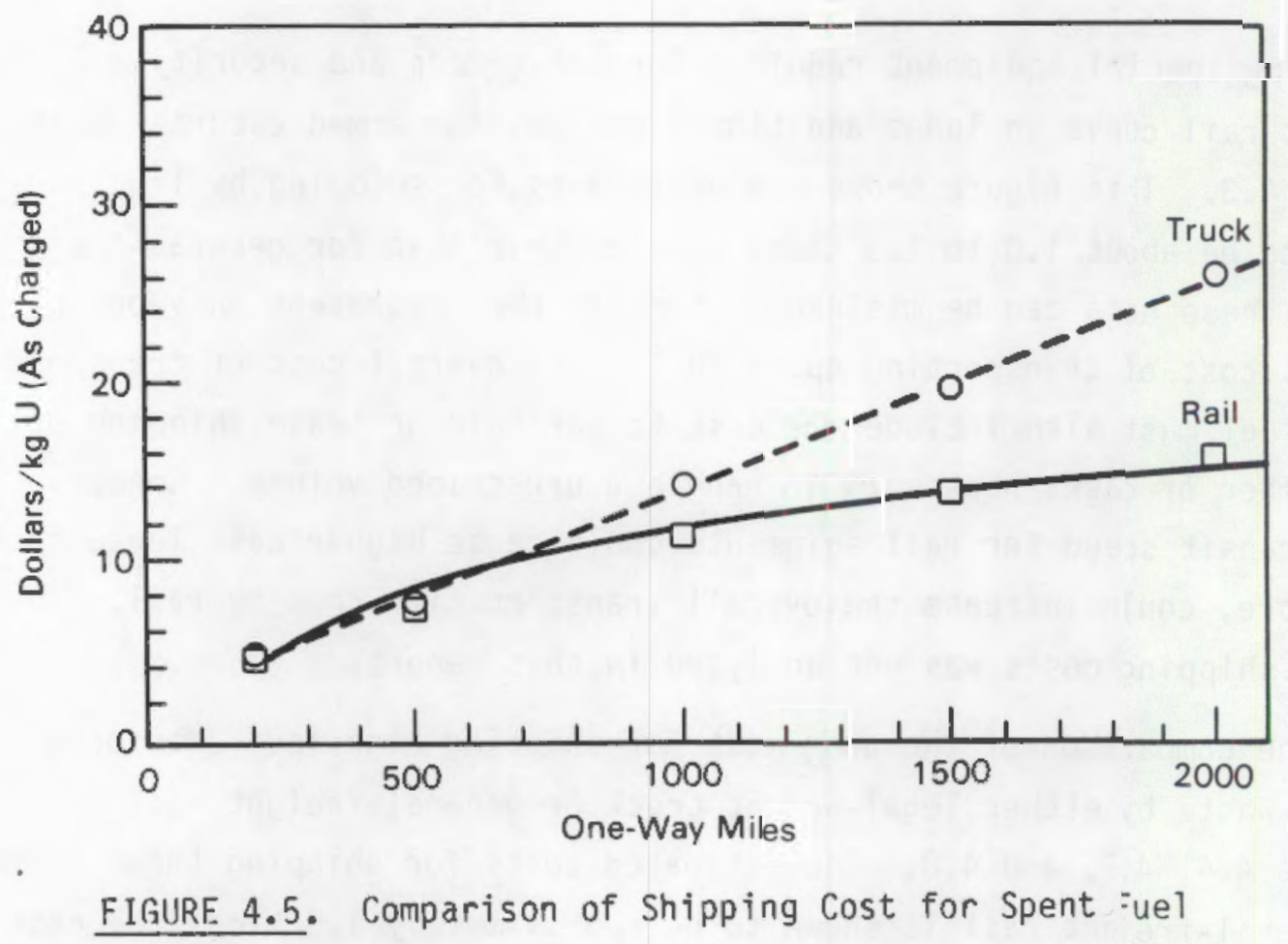

$$
4.4
$$




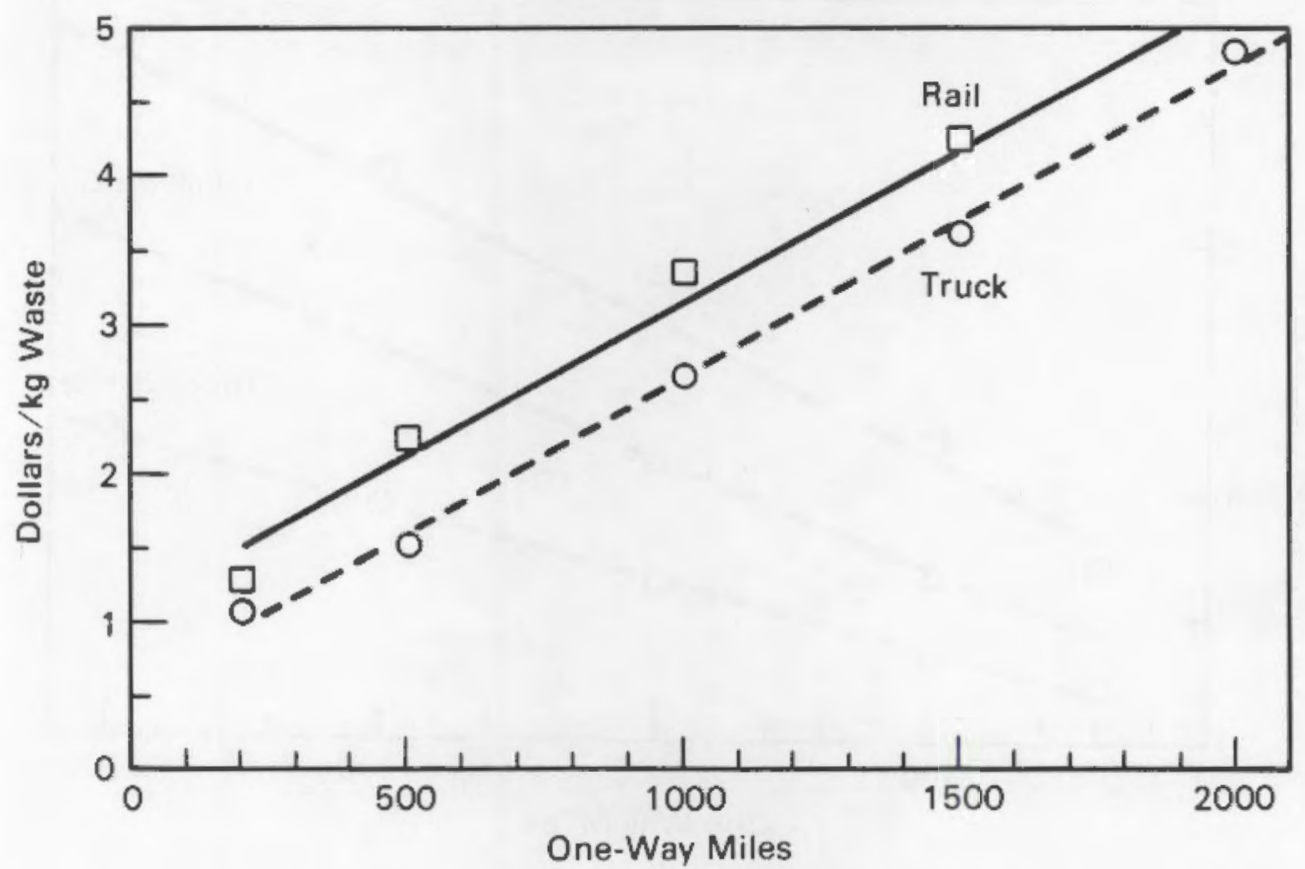

FIGURE 4.6. Comparison of Shipping Cost for High Level Waste

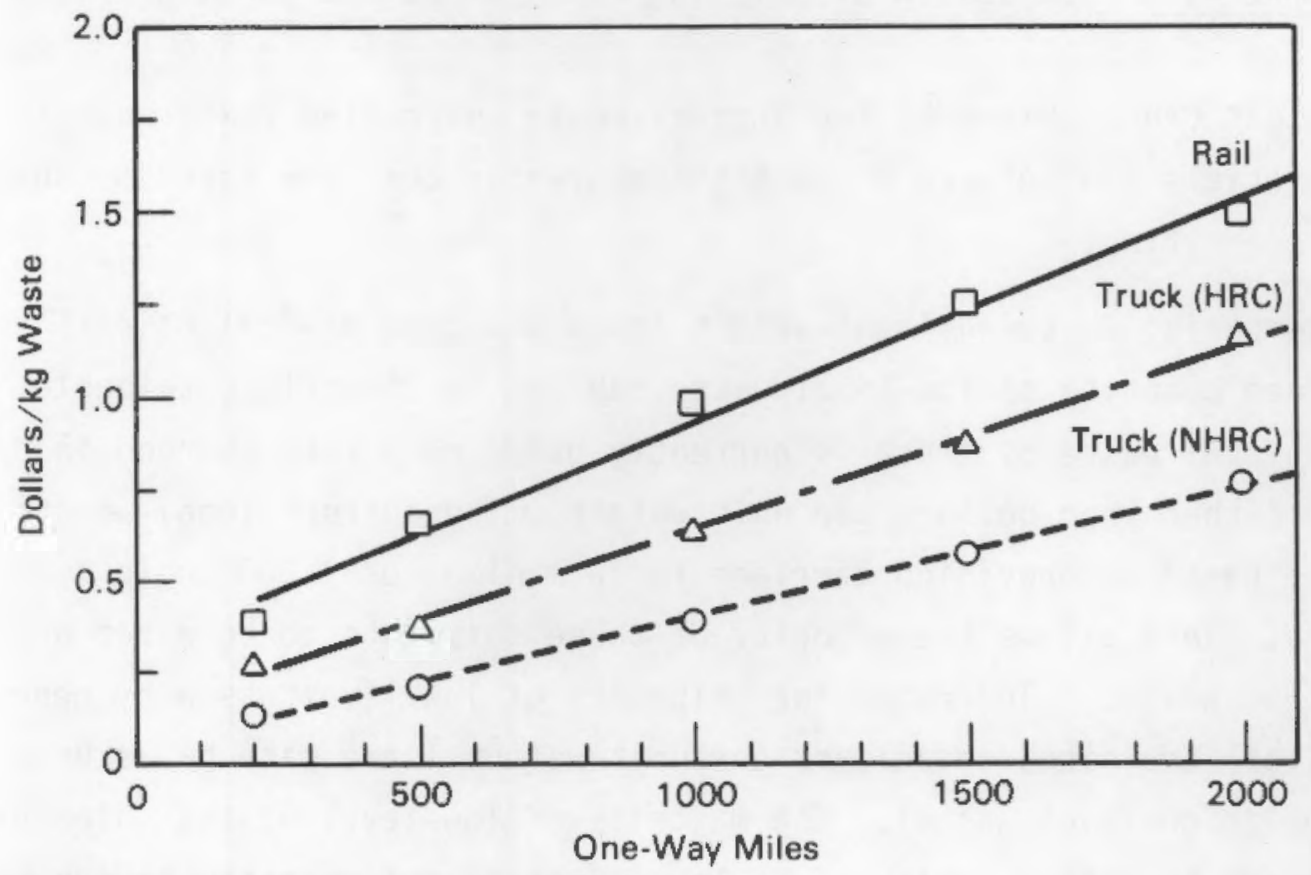

NHRC $=$ Non-Highway Route Controlled

HRC = Highway Route Controlled

FIGURE 4.7. Comparison of Shipping Cost for Contact Handled TRU Waste 


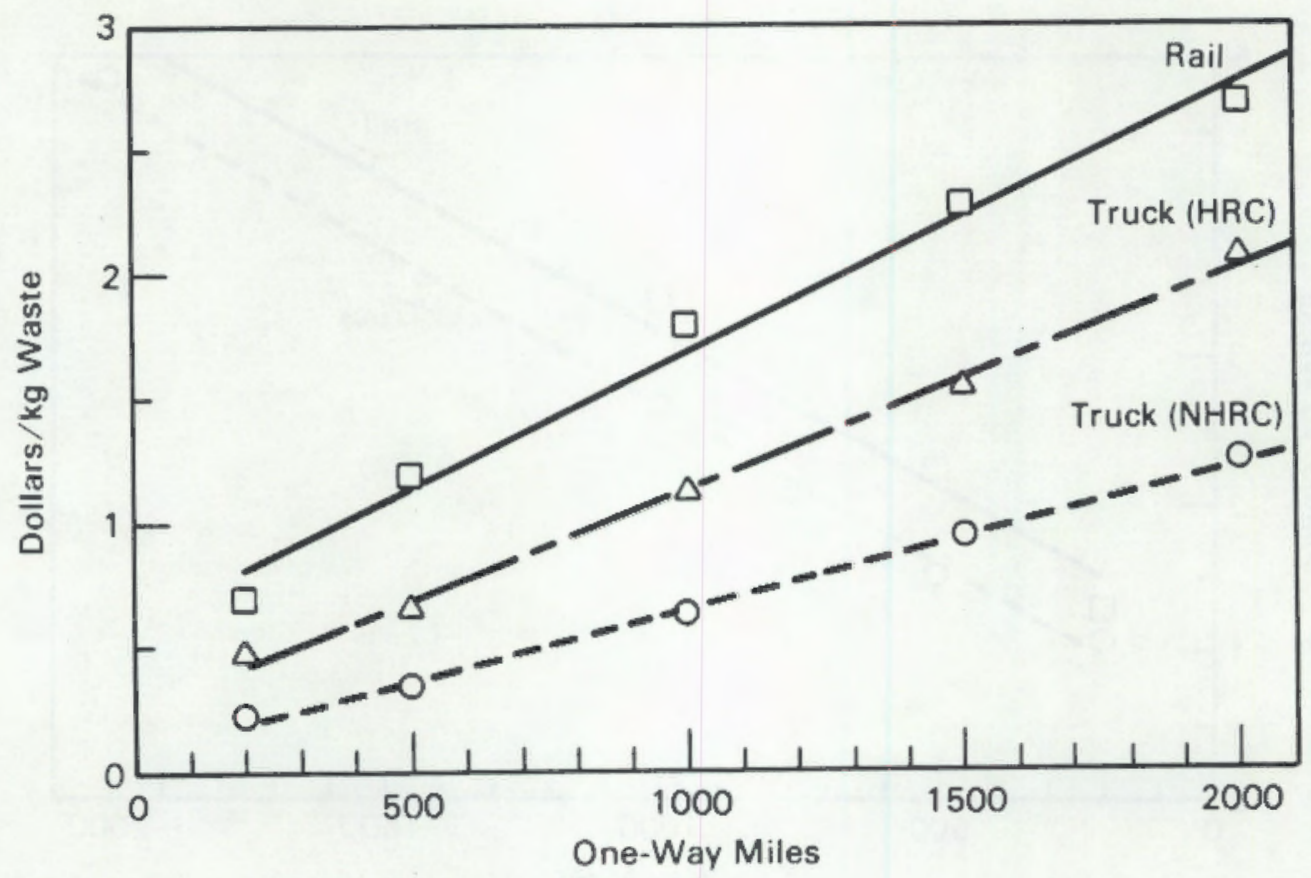

NHRC $=$ Non-Highway Route Controlled $\mathrm{HRC}=$ Highway Route Controlled

FIGURE 4.8. Comparison of Shipping Cost for Remote Handled TRU Waste

legal-weight truck shipments for highway route controlled (HRC) quantities of these materials and between 2 and 6 times greater than the cost for shipping non-HRC quantities.

A comparison between legal-weight truck and general-freight rail shipments for a given quantity of low-level waste may not be directly obtainable. Shipping low-level waste by truck is currently based on a rate charged in dollars per mile rather than dollars per unit weight. The current legal-weight truck rates are based on providing carriage for a minimum of 1,500 cubic feet per truckload. This allows the majority of these shipments to be based on volume rather than weight. The rates for shipments of low-level waste hy general freight rail are based on dollars per unit weight (same rate basis used for spent fuel/high-level waste). The majority of low-level wastes shipments have a low weight-to-volume ratio. This low weight-to-volume ratio favors shipments based on volume rather than weight. Thus, the majority of low-level waste shipments are currently being made with legal-weight truck carriers. 


\section{REFERENCES}

U.S. Code of Federal Regulations. 1985. Title 10, Part 73.37 (10 CFR 73).

Pacific Southcoast Freight Bureau. 1984. Freight Tariff ICC PSFB 1016-A. January 1984, San Francisco, California.

Southern Freight Bureau. 1984. Freight Tariff SFA 1011-B. January 1984, Atl anta, Georgia.

Southwestern Freight Bureau. 19B4. Tariff SWFB 1004-Am, 1005-A, 1006-A, 1007-A. January 1984, St. Louis, Missouri.

Traffic Executive Association - Eastern Railroads. 1984. Freight Tariff TEA 1009-A. January 1984, New York, New York.

Traffic Executive Association - Eastern Railroads. 1984. Freight Tariff TEA 2009-k. Item 80671, January 1984, New York, New York.

Trans-Continental Freight Bureau. 1984. Freight Tariff TCFB 1015-B. January 1984, Chicago, I11 inois.

Tri-State Motor Transit Co. 1984. Docket No. MC-109397. ICC TRSM 4007-A, issued September 10, 1984, Joplin, Missouri.

Western Trunk Lines, 1982. Freight Tariff WTL 1007-A, 1001-A. January 1982, St. Louis, Missouri.

Western Trunk Lines. Freight Tariff WTL 9100 EC-WRTA 265-D. St. Louis, Missouri. 
APPENDIX A

LEGAL WEIGHT TRUCK AND GENERAL FREIGHT RAIL FEE SCHEDULES 
APPENDIX A - LEGAL WEIGHT TRUCK AND GENERAL FREIGHT RAIL FEE SCHEDULES

TABLE A.1A. Truck Shipping Charges for Highway Route Controlled Materials Rates in Cents per 100 Pounds

\begin{tabular}{|c|c|c|c|c|c|}
\hline $\begin{array}{c}\text { Miles } \\
\text { (Not Over) }\end{array}$ & Column $1^{\{a\rangle}$ & Column $2^{(b)}$ & $\begin{array}{c}\text { Miles } \\
\text { (Not Over) }\end{array}$ & Columin $1^{(a)}$ & Column $2^{(a)}$ \\
\hline $\begin{array}{l}100 \\
110 \\
120 \\
130 \\
140\end{array}$ & $\begin{array}{l}158 \\
166 \\
167 \\
172 \\
178\end{array}$ & $\begin{array}{l}106 \\
107 \\
111 \\
114 \\
117\end{array}$ & $\begin{array}{l}825 \\
850 \\
875 \\
900 \\
925\end{array}$ & $\begin{array}{l}443 \\
448 \\
462 \\
467 \\
475\end{array}$ & $\begin{array}{l}348 \\
356 \\
366 \\
378 \\
392\end{array}$ \\
\hline $\begin{array}{l}150 \\
160 \\
170 \\
180 \\
190\end{array}$ & $\begin{array}{l}184 \\
191 \\
198 \\
210 \\
215\end{array}$ & $\begin{array}{l}119 \\
120 \\
123 \\
126 \\
131\end{array}$ & $\begin{array}{r}950 \\
975 \\
1000 \\
1025 \\
1050\end{array}$ & $\begin{array}{l}487 \\
495 \\
503 \\
513 \\
530\end{array}$ & $\begin{array}{l}401 \\
411 \\
420 \\
433 \\
443\end{array}$ \\
\hline $\begin{array}{l}200 \\
225 \\
250 \\
275 \\
300\end{array}$ & $\begin{array}{l}225 \\
232 \\
244 \\
252 \\
259\end{array}$ & $\begin{array}{l}134 \\
141 \\
150 \\
151 \\
157\end{array}$ & $\begin{array}{l}1075 \\
1100 \\
1125 \\
1150 \\
1175\end{array}$ & $\begin{array}{l}541 \\
556 \\
568 \\
578 \\
595\end{array}$ & $\begin{array}{l}450 \\
461 \\
477 \\
484 \\
492\end{array}$ \\
\hline $\begin{array}{l}325 \\
350 \\
375 \\
400 \\
425\end{array}$ & $\begin{array}{l}269 \\
279 \\
284 \\
294 \\
306\end{array}$ & $\begin{array}{l}168 \\
173 \\
174 \\
178 \\
191\end{array}$ & $\begin{array}{l}1200 \\
1225 \\
1250 \\
1275 \\
1300\end{array}$ & $\begin{array}{l}603 \\
618 \\
631 \\
644 \\
656\end{array}$ & $\begin{array}{l}505 \\
514 \\
526 \\
536 \\
547\end{array}$ \\
\hline $\begin{array}{l}450 \\
475 \\
500 \\
525 \\
550\end{array}$ & $\begin{array}{l}314 \\
321 \\
332 \\
337 \\
345\end{array}$ & $\begin{array}{l}197 \\
205 \\
213 \\
229 \\
238\end{array}$ & $\begin{array}{l}1325 \\
1350 \\
1375 \\
1400 \\
1425\end{array}$ & $\begin{array}{l}667 \\
683 \\
693 \\
706 \\
719\end{array}$ & $\begin{array}{l}556 \\
567 \\
579 \\
589 \\
598\end{array}$ \\
\hline $\begin{array}{l}575 \\
600 \\
625 \\
650 \\
675\end{array}$ & $\begin{array}{l}358 \\
365 \\
374 \\
382 \\
391\end{array}$ & $\begin{array}{r}247 \\
258 \\
270 \\
283 \\
\cdot 287\end{array}$ & $\begin{array}{l}1450 \\
1475 \\
1500 \\
1525 \\
1550\end{array}$ & $\begin{array}{l}729 \\
746 \\
756 \\
768 \\
783\end{array}$ & $\begin{array}{l}608 \\
621 \\
629 \\
643 \\
653\end{array}$ \\
\hline $\begin{array}{l}700 \\
725 \\
750 \\
775 \\
800\end{array}$ & $\begin{array}{l}399 \\
409 \\
417 \\
424 \\
433\end{array}$ & $\begin{array}{l}294 \\
312 \\
322 \\
327 \\
336\end{array}$ & $\begin{array}{l}1575 \\
1600 \\
1625 \\
1650 \\
1675\end{array}$ & $\begin{array}{l}794 \\
808 \\
822 \\
830 \\
846\end{array}$ & $\begin{array}{l}661 \\
671 \\
684 \\
692 \\
704\end{array}$ \\
\hline
\end{tabular}

(a) 36,000 pounds per vehicle minimum charge

(b) 32,000 pounds per vehicle minimum charge 
TABLE A.1A. (contd)

Rates in Cents per 100 Pounds

\begin{tabular}{|c|c|c|c|c|c|}
\hline $\begin{array}{c}\text { Miles } \\
\text { (Not Over) }\end{array}$ & Column $1^{(a)}$ & Column $2^{(b)}$ & $\begin{array}{c}\text { Miles } \\
\text { (Not Over) } \\
\end{array}$ & Column $1^{(a)}$ & Column $2^{(a)}$ \\
\hline $\begin{array}{l}1700 \\
1725 \\
1750 \\
1775 \\
1800\end{array}$ & $\begin{array}{l}857 \\
868 \\
883 \\
893 \\
908\end{array}$ & $\begin{array}{l}714 \\
733 \\
742 \\
754 \\
768\end{array}$ & $\begin{array}{l}2700 \\
2750 \\
2800 \\
2850 \\
2900\end{array}$ & $\begin{array}{l}1361 \\
1387 \\
1411 \\
1438 \\
1461\end{array}$ & $\begin{array}{l}1146 \\
1163 \\
1188 \\
1207 \\
1230\end{array}$ \\
\hline $\begin{array}{l}1825 \\
1850 \\
1875 \\
1900 \\
1925\end{array}$ & $\begin{array}{l}919 \\
932 \\
944 \\
960 \\
971\end{array}$ & $\begin{array}{l}774 \\
783 \\
796 \\
810 \\
818\end{array}$ & $\begin{array}{l}2950 \\
3000 \\
3050 \\
3100 \\
3150\end{array}$ & $\begin{array}{l}1489 \\
1510 \\
1538 \\
1563 \\
1588\end{array}$ & $\begin{array}{l}1245 \\
1272 \\
1292 \\
1309 \\
1331\end{array}$ \\
\hline $\begin{array}{l}1950 \\
1975 \\
2000 \\
2025 \\
2050\end{array}$ & $\begin{array}{r}981 \\
998 \\
1007 \\
1022 \\
1034\end{array}$ & $\begin{array}{l}825 \\
838 \\
847 \\
856 \\
869\end{array}$ & $\begin{array}{l}3200 \\
3250 \\
3300 \\
3350 \\
3400\end{array}$ & $\begin{array}{l}1615 \\
1640 \\
1666 \\
1687 \\
1715\end{array}$ & $\begin{array}{l}1355 \\
1380 \\
1395 \\
1419 \\
1442\end{array}$ \\
\hline $\begin{array}{l}2075 \\
2100 \\
2125 \\
2150 \\
2175\end{array}$ & $\begin{array}{l}1047 \\
1060 \\
1071 \\
1082 \\
1093\end{array}$ & $\begin{array}{l}881 \\
890 \\
899 \\
912 \\
921\end{array}$ & $\begin{array}{l}3450 \\
3500 \\
3550 \\
3600 \\
3650\end{array}$ & $\begin{array}{l}1741 \\
1766 \\
1789 \\
1815 \\
1840\end{array}$ & $\begin{array}{l}1461 \\
1482 \\
1502 \\
1525 \\
1548\end{array}$ \\
\hline $\begin{array}{l}2200 \\
2250 \\
2300 \\
2350 \\
2400\end{array}$ & $\begin{array}{l}1110 \\
1136 \\
1161 \\
1186 \\
1212\end{array}$ & $\begin{array}{l}934 \\
953 \\
976 \\
997 \\
942\end{array}$ & $\begin{array}{l}3700 \\
3750 \\
3800 \\
3850 \\
3900\end{array}$ & $\begin{array}{l}1867 \\
1891 \\
1916 \\
1939 \\
1968\end{array}$ & $\begin{array}{l}1564 \\
1592 \\
1611 \\
1532 \\
1651\end{array}$ \\
\hline $\begin{array}{l}2450 \\
2500 \\
2550 \\
2600 \\
2650\end{array}$ & $\begin{array}{l}1239 \\
1258 \\
1284 \\
1310 \\
1336\end{array}$ & $\begin{array}{l}1039 \\
1062 \\
1080 \\
1103 \\
1122\end{array}$ & $\begin{array}{l}3950 \\
4000 \\
4050 \\
4100 \\
4150\end{array}$ & $\begin{array}{l}1993 \\
2019 \\
2042 \\
2066 \\
2090\end{array}$ & $\begin{array}{l}1674 \\
1695 \\
1719 \\
1738 \\
1759\end{array}$ \\
\hline & & & $\begin{array}{l}4200 \\
4250 \\
4300\end{array}$ & $\begin{array}{l}2120 \\
2143 \\
2167\end{array}$ & $\begin{array}{l}1780 \\
1798 \\
1822\end{array}$ \\
\hline
\end{tabular}

(a) 36,000 pounds per vehicle minimum charge

(b) 32,000 pounds per vehicle minimum charge 
TABLE A.1B. Truck Shipping Charges for Non-Highway Route Controlled Materials

\begin{tabular}{|c|c|c|c|c|c|c|c|}
\hline In (noway Mi l leage & Col ymm ${ }^{(a)}$ & Col $2^{m n}{ }^{(b)}$ & Colugn ${ }^{(c)}$ & One Nał Mil Overige & Column ${ }^{(a)}$ & Col umen ${ }^{(b)}$ & Colugn ${ }^{(c)}$ \\
\hline $\begin{array}{l}100 \\
125 \\
150\end{array}$ & $\begin{array}{l}471 \\
433 \\
396\end{array}$ & $\begin{array}{l}495 \\
459 \\
423\end{array}$ & $\begin{array}{l}338 \\
313 \\
289\end{array}$ & $\begin{array}{l}750 \\
800 \\
850\end{array}$ & $\begin{array}{l}173 \\
165 \\
164\end{array}$ & $\begin{array}{l}209 \\
203 \\
202\end{array}$ & $\begin{array}{l}142 \\
142 \\
142\end{array}$ \\
\hline $\begin{array}{l}175 \\
200 \\
225\end{array}$ & $\begin{array}{l}362 \\
313 \\
296\end{array}$ & $\begin{array}{l}389 \\
343 \\
329\end{array}$ & $\begin{array}{l}268 \\
245 \\
233\end{array}$ & $\begin{array}{r}900 \\
950 \\
1000\end{array}$ & $\begin{array}{l}162 \\
159 \\
156\end{array}$ & $\begin{array}{l}200 \\
197 \\
193\end{array}$ & $\begin{array}{l}142 \\
142 \\
142\end{array}$ \\
\hline $\begin{array}{l}250 \\
275 \\
300\end{array}$ & $\begin{array}{l}284 \\
27 ! \\
259\end{array}$ & $\begin{array}{l}315 \\
304 \\
291\end{array}$ & $\begin{array}{l}217 \\
204 \\
194\end{array}$ & $\begin{array}{l}1100 \\
1200 \\
1300\end{array}$ & $\begin{array}{l}156 \\
156 \\
156\end{array}$ & $\begin{array}{l}192 \\
190 \\
188\end{array}$ & $\begin{array}{l}142 \\
142 \\
142\end{array}$ \\
\hline $\begin{array}{l}325 \\
350 \\
375\end{array}$ & $\begin{array}{l}252 \\
244 \\
235\end{array}$ & $\begin{array}{l}285 \\
278 \\
268\end{array}$ & $\begin{array}{l}183 \\
177 \\
171\end{array}$ & $\begin{array}{l}1400 \\
1500 \\
1600\end{array}$ & $\begin{array}{l}156 \\
156 \\
156\end{array}$ & $\begin{array}{l}187 \\
186 \\
184\end{array}$ & $\begin{array}{l}142 \\
142 \\
142\end{array}$ \\
\hline $\begin{array}{l}400 \\
425 \\
450\end{array}$ & $\begin{array}{l}224 \\
217 \\
207\end{array}$ & $\begin{array}{l}258 \\
252 \\
242\end{array}$ & $\begin{array}{l}165 \\
162 \\
158\end{array}$ & $\begin{array}{l}1700 \\
1800 \\
1900\end{array}$ & $\begin{array}{l}156 \\
\$ 56 \\
156\end{array}$ & $\begin{array}{l}183 \\
182 \\
181\end{array}$ & $\begin{array}{l}142 \\
142 \\
142\end{array}$ \\
\hline $\begin{array}{l}475 \\
500 \\
550\end{array}$ & $\begin{array}{l}202 \\
194 \\
190\end{array}$ & $\begin{array}{l}237 \\
230 \\
225\end{array}$ & $\begin{array}{l}155 \\
152 \\
149\end{array}$ & $\begin{array}{l}2000 \\
2100 \\
2200\end{array}$ & $\begin{array}{l}156 \\
156 \\
156\end{array}$ & $\begin{array}{l}180 \\
179 \\
177\end{array}$ & $\begin{array}{l}142 \\
142 \\
142\end{array}$ \\
\hline $\begin{array}{l}600 \\
650 \\
700\end{array}$ & $\begin{array}{l}185 \\
176 \\
169\end{array}$ & $\begin{array}{l}222 \\
211 \\
203\end{array}$ & $\begin{array}{l}142 \\
142 \\
137\end{array}$ & $\begin{array}{ll} & 2300 \\
2400 & \\
2500 \text { \& Beyond }\end{array}$ & $\begin{array}{l}156 \\
156 \\
156\end{array}$ & $\begin{array}{l}176 \\
175 \\
174\end{array}$ & $\begin{array}{l}142 \\
142 \\
142\end{array}$ \\
\hline
\end{tabular}

(a) Applicable to one-way shipments heving a destination east of the Mlssisslppi River.

(b) Applicable to one-way shlpments havling a destination west of the Misslsslppi River.

(c) Applicable to continuous excursion moves in which a subsequent shipment is made available to carrler within 24 hours after arrival. 
TABLE A.2. Truck Overweight Charges for Traveling Through Each State
Exc?uding Alaska and Hawa $i$ (a)

\begin{tabular}{|c|c|c|c|}
\hline State & $\begin{array}{l}\text { When Weight of } \\
\text { Article Exceeds } \\
\text { (1lbs) }\end{array}$ & & $\begin{array}{l}\text { rweight Charge Applicable per } \\
\text { Vehicles IJsed (\$) }\end{array}$ \\
\hline Al abama & 48,000 & $\begin{array}{r}38.00 \\
58.00 \\
88.00 \\
128.00\end{array}$ & $\begin{array}{l}\text { up to } 65,000 \text { lbs } \\
\text { from } 65,001 \text { to } 85,000 \text { lbs } \\
\text { from } 85,001 \text { to } 110,000 \text { lbs } \\
\text { for weight of } 110,001 \text { ibs or } \\
\text { more }\end{array}$ \\
\hline Arizona & 48,000 & 20.00 & \\
\hline Arkansas & 48,000 & 17.00 & 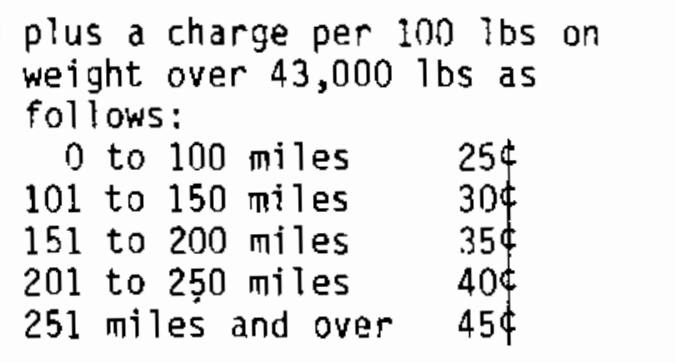 \\
\hline California & 48,000 & 33.00 & \\
\hline Colorado & 48,000 & 23.00 & \\
\hline Connecticut & 48,000 & 35.00 & \\
\hline Del aware & 48,000 & 18.00 & $\begin{array}{l}\text { plus } 2 \$ \text { per ton mile traveled in } \\
\text { Delaware on the weight over } \\
48,000 \text { lbs }\end{array}$ \\
\hline Florida & 48,000 & $\begin{array}{l}35.00 \\
40.00 \\
40.00\end{array}$ & $\begin{array}{l}\text { per load on articles weighting } \\
48,001 \text { to } 57,0001 \text { bs } \\
\text { per load on articles weighing } \\
\text { between } 57,0001 \text { bs and } 74,000 \\
\text { lbs } \\
\text { per load plus } 25 \$ \text { per } 1000 \text { lbs } \\
\text { on weight over } 74,000 \text { lbs }\end{array}$ \\
\hline Georgia & 48,000 & 30.00 & \\
\hline Idaho & 48,000 & 30.00 & \\
\hline
\end{tabular}

(a) These charges are applicable only when overweight permits are required. 
TABLE A.2. (contd)

When weight of

Article Exceeds

State

Illinois

Indi ana

48,000

43,000

Iowa

Kansas

Kentucky

Louisiana

Maine

Maryl and

Massachusetts

Michigan

Minnesota
48,000

48,000

48,000

48,000

48,000

48,000

48,000

48,000

48,000
Overweight Charge Applicable per Vehicles Used (\$)

30.00 plus $30 \$$ per mile traveled in Illinois on shipments over 48,000 to 49,999 tbs plus $50 \varnothing$ per mile on shipments over 50,000 to 69,999 lbs

65.00 plus $50 \Varangle$ per mile on shipments weighing over 70,000 lbs

33.00 plus $40 \$$ per mile traveled in Indiana, subject to a maximum charge of $\$ 75.00$

23.00

23.00

48.00

30.00 plus $40 \$$ per mile traveled in Louisiana, up to 68,000 lbs

40.00 plus $80 \$$ per mile traveled in Louisiana from 68,001 to 88,000 lbs

50.00 plus $\$ 1.20$ per mile traveled in Louisiana from 88,000 to 108,000 lbs

60.00 plus $\$ 2.40$ per mile traveled in Louisiana from 108,001 or more

35.00

45.00 plus $\$ 5.00$ per ton, or fraction thereof, on weight in excess of 50,000 ibs

18.00

45.00

28.00 
TABLE A.2. (contd)

When weight of

Article Exceeds (1bs) 48,000

Mississippi

Missouri

Montana

Nebraska

Nevada

New Hampshire

New Jersey

New Mexico

New York

North Carolina
43,000

48,000

48,000

48,000

48,000

48,000

48,000

48,000

48,000
Overweight Charge Applicable per Vehicles Used (\$)

10.00 plus $15 \$$ per ton mile traveled only on interstate highways; all other highways $30 \notin$ per ton mile in Mississippi on weight in excess of 48,000 lbs

28.50

40.00 on distance of 100 miles or less (in Montana)

60.00 on distance of 101 to 200 miles (in Montana)

80.00 on distance of 201 miles or over (in Montana)

29.00

25.00

44.00 on shipments 48,000 to 58,000 lbs

54.00 on shipments 58,000 to 63,000 1 bs

64.00 on stipments 70,000 lbs plus $\$ 2.00$ per 100 lbs over 70,000 Ibs

50.00 on articies weighing 48,001 to 53,000 1bs

60.00 on articles weighing 53,001 to 58,000 lbs

75.00 on articles weighing 58,001 to 63,000 lbs

125.00 on articles weighing 63,001 to 68,000 1bs

200.00 on articles weighing over 68,000 los

20.00

30.000

23.00 
TABLE A.2. (contd)

\begin{tabular}{|c|c|c|c|}
\hline State & $\begin{array}{l}\text { When weight of } \\
\text { Article Exceeds } \\
\text { (libs) }\end{array}$ & Over & $\begin{array}{l}\text { rweight Charge Applicable per } \\
\text { Vehicles Used }(\$)\end{array}$ \\
\hline North Dakota & 48,000 & 23.00 & $\begin{array}{l}\text { plus } \$ 6.00 \text { per ton in excess of } \\
48,000\end{array}$ \\
\hline Ohio & 48,000 & 38.00 & \\
\hline Ok1 ahoma & 48,000 & 23.00 & $\begin{array}{l}\text { plus } \$ 5.00 \text { for each } 1,000 \text { lbs or } \\
\text { fraction thereof on excess of } \\
48,000 \text { lbs per load }\end{array}$ \\
\hline Oregon & 48,000 & 21.00 & \\
\hline Pennsyivania & 48,000 & 30.00 & $\begin{array}{l}\text { plus } 3 \$ \text { per ton mile on excess } \\
\text { of } 48,000 \text { lbs per load when } \\
\text { weight exceeds } 98,000 \text { 1bs charge } \\
4 \$ \text { per ton }\end{array}$ \\
\hline Rhode Island & 48,000 & 18.00 & \\
\hline South Carolina & 48,000 & 23.00 & \\
\hline South Oakota & 48,000 & 30.00 & $\begin{array}{l}\text { plus } 2 \$ \text { per ton mile on excess } \\
\text { of } 48,000 \text { Tbs }\end{array}$ \\
\hline Tennessee & 48,000 & 40.00 & $\begin{array}{l}\text { plus } 5 \$ \text { per ton mile traveled in } \\
\text { TN on weight in excess of } 48 M\end{array}$ \\
\hline Texas & 48,000 & 19.00 & \\
\hline Iftah & 48,000 & 74.00 & \\
\hline Vermont & 48,000 & 40.00 & \\
\hline Virginia & 48,000 & 28.00 & $\begin{array}{l}\text { plus } 10 \$ \text { per mile traveled in } \\
\text { Virginia }\end{array}$ \\
\hline Washington & 48,000 & $\begin{array}{l}25.00 \\
10 \notin \mathrm{p} \\
20 \notin \mathrm{P} \\
30 £ \mathrm{p} \\
45 \notin \mathrm{P} \\
75 \notin \mathrm{P} \\
1.00 \\
1.50 \\
1.75 \\
2.00\end{array}$ & $\begin{array}{l}\text { plus a charge of: } \\
\text { per mile on } 48,000 \text { to } 56,999 \text { lbs } \\
\text { ber mile on } 57,000 \text { to } 62,999 \text { lbs } \\
\text { per mile on } 63,000 \text { to } 68,999 \text { ibs } \\
\text { per mile on } 69,000 \text { to } 74,999 \text { ibs } \\
\text { per mile on } 75,000 \text { to } 80,999 \text { lbs } \\
\text { per mile on } 81,000 \text { to } 86,999 \text { ibs } \\
\text { per mile on } 87,000 \text { to } 92,999 \text { lbs } \\
\text { per mile on } 93,000 \text { to } 98,999 \text { lbs } \\
\text { per mile on } 99,000 \text { lbs or over }\end{array}$ \\
\hline
\end{tabular}


IABLE A.2. (contd)

\begin{tabular}{|c|c|c|}
\hline State & $\begin{array}{c}\text { When Weight of } \\
\text { Article Exceeds } \\
\text { (lbs) }\end{array}$ & $\begin{array}{c}\text { Overweight Charge Applicable per } \\
\text { Vehicles Used } \$ \$ \text { ( }\end{array}$ \\
\hline West Virginia & 48,000 & $\begin{array}{l}20.00 \text { plus } 3 \$ \text { per ton mile on excess } \\
\text { of } 48,000 \text { los per load }\end{array}$ \\
\hline Wiscons in & 48,000 & $\begin{array}{l}35.00 \text { articles up to } 58.00 \mathrm{lbs} \\
5.0058,001 \text { to } 68,000 \mathrm{bbs} \\
60.0068,001 \text { to } 78,000 \mathrm{lbs} \\
70.0078,001 \text { to } 88,000 \mathrm{lbs} \\
80.0088,001 \text { to } 98,000 \mathrm{lbs} \\
90.0098,001 \text { to } 108,000 \mathrm{lbs} \\
100.00 \text { 108,000 to } 118,000 \mathrm{lbs} \text { plus } 1.00 \\
\text { per } 1000 \text { lbs over } 118,000 \text { lbs }\end{array}$ \\
\hline Wyoming & 48,000 & $\begin{array}{l}21.00 \text { plus } 4 \$ \text { per ton mile in excess } \\
\text { of } 48,000 \text { lbs, subject to } \\
\text { maximum charge of } \$ 200.00 \text { (such } \\
\text { maximum charge will NOT apply to } \\
\text { towaway shipments) }\end{array}$ \\
\hline
\end{tabular}


TABLE A.3. Truck Surcharges

\begin{tabular}{|c|c|c|c|}
\hline Type of Charge & Commodity & Cost & NRC Requirement \\
\hline $\begin{array}{l}\text { Special equipment } \\
\text { (legal-size and legal- } \\
\text { weight) }\end{array}$ & Spent fuel & $\$ 0.92$ per loaded mile & $x$ \\
\hline $\begin{array}{l}\text { Special equipment } \\
\text { (oversize or overweight) }\end{array}$ & Spent fuel & $\$ 1.00$ per loaded mile & $x$ \\
\hline "L" cleared driver & $\mathrm{HRC}^{(\mathrm{a})}$ & $\$ 0.12$ per mile & \\
\hline "Q" cleared driver & $\mathrm{HRC}^{(\mathrm{a})}$ & $\$ 0.15$ per mile $\mathrm{e}^{(\mathrm{b})}$ & \\
\hline Armed driver/escort & Spent fuel & $\$ 0.20$ per mile & $x$ \\
\hline Separate escort vehicle & Spent fuel & $\$ 1.48$ per mile & $x^{(c)}$ \\
\hline $\begin{array}{l}\text { Highway route control } \\
\text { surcharge }\end{array}$ & $H R C^{(d)}$ & $\$ 0.45$ per mile $(e)$ & \\
\hline
\end{tabular}

(a) Highway route controlled.

(b) For two " 0 " cleared drivers, a fixed charge of $\$ 200$.

(c) Required in heavily populated areas.

(d) Is not imposed on spent fuel shipments.

(e) Minimum charge of $\$ 450$. 
TABLE A.4. Truck Detention Charges

\begin{tabular}{|c|c|c|}
\hline Hours & $\begin{array}{l}\text { Rate Per Hour } \\
\text { Spent Fuel } \\
\end{array}$ & $\begin{array}{l}\text { Per Vehicle Used } \\
\text { Nuclear Waste } \\
\text { Nuclear }\end{array}$ \\
\hline First 3 & Free & Free \\
\hline $4-8$ & $\$ 17.50$ & $\$ 17.50$ \\
\hline $9-16$ & $\$ 22.50$ & $\$ 17.50$ \\
\hline $17-24$ & $\$ 27.50$ & $\$ 17.50$ \\
\hline over 24 & $\$ 32.50$ & $\$ 17.50$ \\
\hline
\end{tabular}

(a) Maximum detention charge for any one calendar day shall be the charge for ten (10) hours time except, when vehicle is not loaded and/or unloaded and vehicle is not released to carrier within 24 hours after arrival, detention charges thereafter shal1 be $\$ 17.50$ per hour with no exclusions for hours of day, holidays or Sunday. 
TABLE A.5. Summary of Loaded and Empty Packaging Weights Used in Analysis of Shipping Costs

\begin{tabular}{|c|c|c|c|c|c|c|c|c|}
\hline \multirow[b]{3}{*}{ Cominodity } & \multicolumn{4}{|c|}{ Legal Weight Truck } & \multicolumn{4}{|c|}{ General Freight Rail } \\
\hline & Loadec & Weight & Empty & Weight & Loaded & eight & Empty & Weight \\
\hline & $1 \mathrm{~b}$ & $\mathrm{~kg}$ & $1 \mathrm{~b}$ & $\mathrm{~kg}$ & $1 \mathrm{~b}$ & $\mathrm{~kg}$ & $1 \mathrm{~b}$ & $\mathrm{~kg}$ \\
\hline Spent Fuel & 50,000 & 22,680 & 48,650 & 22,068 & 180,000 & 81,648 & 169,000 & 76,658 \\
\hline High-Level Waste & 50,000 & 22,680 & 45,500 & 20,638 & 200,000 & 90,720 & 177,500 & 80,514 \\
\hline RH-Tru Waste & 50,000 & 22,680 & 40,000 & 18,144 & 200,000 & 90,720 & 160,000 & 72,576 \\
\hline CH-Tru Waste & 50,000 & 22,680 & 33,000 & 14,969 & 100,000 & 45,360 & 66,000 & 29,938 \\
\hline Low-Level Waste & (a) & (a) & (a) & (a) & (b) & (b) & (c) & (c) \\
\hline
\end{tabular}

\footnotetext{
(a) Based on $\$ / m i l e$ (no weight required)

(b) Assumed shipment weight of 150,000 pounds.

(c) Minimum weight assumed (40,000 pounds)
} 
TABLE A.6. Rail General-Freight Shipping Charges, Distances, and Transit Times from All LWRs to National Site

\begin{tabular}{|c|c|c|c|c|c|}
\hline State/Town & Reactor & $\begin{array}{r}\text { Doll } \\
\text { Per 100 } \\
\text { Loaded } \\
\end{array}$ & $\begin{array}{l}\text { Pounds } \\
\text { Empty }\end{array}$ & $\begin{array}{l}\text { Approximate } \\
\text { Raj1 Miles } \\
\end{array}$ & $\begin{array}{l}\text { Transit } \\
\text { Time, Days } \\
\end{array}$ \\
\hline$\frac{\text { ALABAMA }}{\text { Scottsboro }}$ & Bellefonte 1,2 & 9.67 & 9.06 & 1,171 & $8-11$ \\
\hline$\frac{\text { ARIZONA }}{\text { Wintersburg }}$ & Palo Verde $1,2,3$ & 9.61 & 9.01 & 602 & $4-6$ \\
\hline$\frac{\text { ARKANSAS }}{\text { RusseTville }}$ & Arkansas Nuclear $1, ?$ & 7.51 & 7.04 & 749 & $7-10$ \\
\hline $\begin{array}{l}\text { CAL IFORNIA } \\
\text { Clay Station } \\
\text { Eureka } \\
\text { San Clemente }\end{array}$ & $\begin{array}{l}\text { Ranco Seco } \\
\text { Humboldt Bay } \\
\text { San Onofre, } 1,2,3\end{array}$ & $\begin{array}{l}13.88 \\
13.45 \\
13.45\end{array}$ & $\begin{array}{l}13.02 \\
12.61 \\
12.61\end{array}$ & $\begin{array}{r}1346 \\
1591 \\
941\end{array}$ & $\begin{array}{l}9-12 \\
9-12 \\
7-10\end{array}$ \\
\hline$\frac{\text { CONNECTICUT }}{\text { Waterford }}$ & Millstone $1,2,3$ & 14.90 & 13.97 & 2,195 & $10-13$ \\
\hline$\frac{\text { FLORIDA }}{\text { Redlevel }}$ & Crystal River 3 & 11.33 & 10.62 & 1,478 & $10-13$ \\
\hline $\begin{array}{l}\frac{\text { GEORGIA }}{\text { Bax?ey }} \\
\text { Waynesboro }\end{array}$ & $\begin{array}{l}\text { Hatch } 1, ? \\
\text { Vogt le } 1,2\end{array}$ & $\begin{array}{l}10.68 \\
10.98\end{array}$ & $\begin{array}{l}10.02 \\
10.29\end{array}$ & $\begin{array}{l}1,371 \\
1,425\end{array}$ & $\begin{array}{l}8-11 \\
9-12\end{array}$ \\
\hline $\begin{array}{l}\text { ILLINOIS } \\
\text { Braidwood } \\
\text { Byron } \\
\text { Clinton } \\
\text { Cordova } \\
\text { Morris } \\
\text { Seneca } \\
\text { Zion }\end{array}$ & $\begin{array}{l}\text { Braidwood } 1,2 \\
\text { Byron } 1,2 \\
\text { Clinton } 1 \\
\text { Ouad Cities } 1,2 \\
\text { Dresden } 1,2,3 \\
\text { LaSalle County } 1,2 \\
\text { Zion } 1, ?\end{array}$ & $\begin{array}{r}9.93 \\
9.93 \\
9.57 \\
9.45 \\
9.93 \\
9.93 \\
10.22\end{array}$ & $\begin{array}{l}9.31 \\
9.31 \\
8.97 \\
8.86 \\
9.31 \\
9.31 \\
9.58\end{array}$ & $\begin{array}{l}1,206 \\
1,221 \\
1,149 \\
1,125 \\
1,206 \\
1,206 \\
1,267\end{array}$ & $\begin{array}{l}6-8 \\
6-8 \\
6-8 \\
6-8 \\
6-8 \\
6-8 \\
6-8\end{array}$ \\
\hline$\frac{\text { INDIANA }}{\text { Madison }}$ & Marble Hill 1,2 & 10.46 & 9.81 & 1,315 & $7-10$ \\
\hline$\frac{\text { IOWA }}{\text { PaTo }}$ & Arnold & 9.45 & 8.86 & 1.107 & $8-11$ \\
\hline$\frac{\text { KANSAS }}{\text { BurTington }}$ & Wolf Creek & 7.40 & 6.94 & 733 & $6-8$ \\
\hline
\end{tabular}


TABLE A.6. (contd)

0oliars

State/Town

LOIJISIANA

St. Francisville Taft

MAINE

Wiscasset

MICHIGAN

Bridgman

Midl and

Newport

MINNESOTA

MonticeTlo

Red Wing

MISSIPPIPPI

Iuka Gibson

MISSOURI

Fulton

NEBRASKA

Brownvil le

Ft. Calhoun

NEW HAMPSHIRE

Seabrook

NEW YORK

Scriba

NORTH CAROLINA Cornelius

New Hiti

South Port

OHIO

North Perry
Oak Harbor

OREGON

Riverbend 1

Waterford 3

8.30

8.52

Main Yankee

15.64

Cook 1,?

Midland 1,2

10.58

11.47

Monticello

11.33

10.32

Prairie Isl and $1,2 \quad 10.06$

Yellow Creek 1,2

Grand Gulf 1,2

8.92

8.03

Callaway 1,2

8.80

Cooper

8.40

Ft. Calhoun 1

8.52

Seabrook 1,2

15.1

Nine Mile Point 1,?

Fitzpatrick

13.34

McGuire 1,2

Harris $1,2,3,4$

Brunswick 1,2

11.56

12.06

12.35

Perry 1,?

11.81

11.47
Per 100 Pounds Approximate Transit

Loaded Empty Rail Miles Time, Days

7.79

892

$9-12$

7.99

936

$9-12$

14.66

2,349

$12-15$

9.92

10.75

1,333

1,507

$9-12$

10.62

1,481

$9-12$

$9-12$

9.68

1,283

9-12

9.43

1,249

$9-12$

8.37

1,012

$9-12$

7.53

838

8-11

8.25

976

8-11

7.88

913

8-11

7.99

949

8-11

14.19

2,239

$10-13$

12.51

1,880

$10-15$

10.84

1,541

1,639

1,687

10-13

10-13

$10-13$

11.07

1,588

12-15

10.75

1,503

$9-12$

Trojan

$16.80 \quad 15.75 \quad 1,680$

8-11 


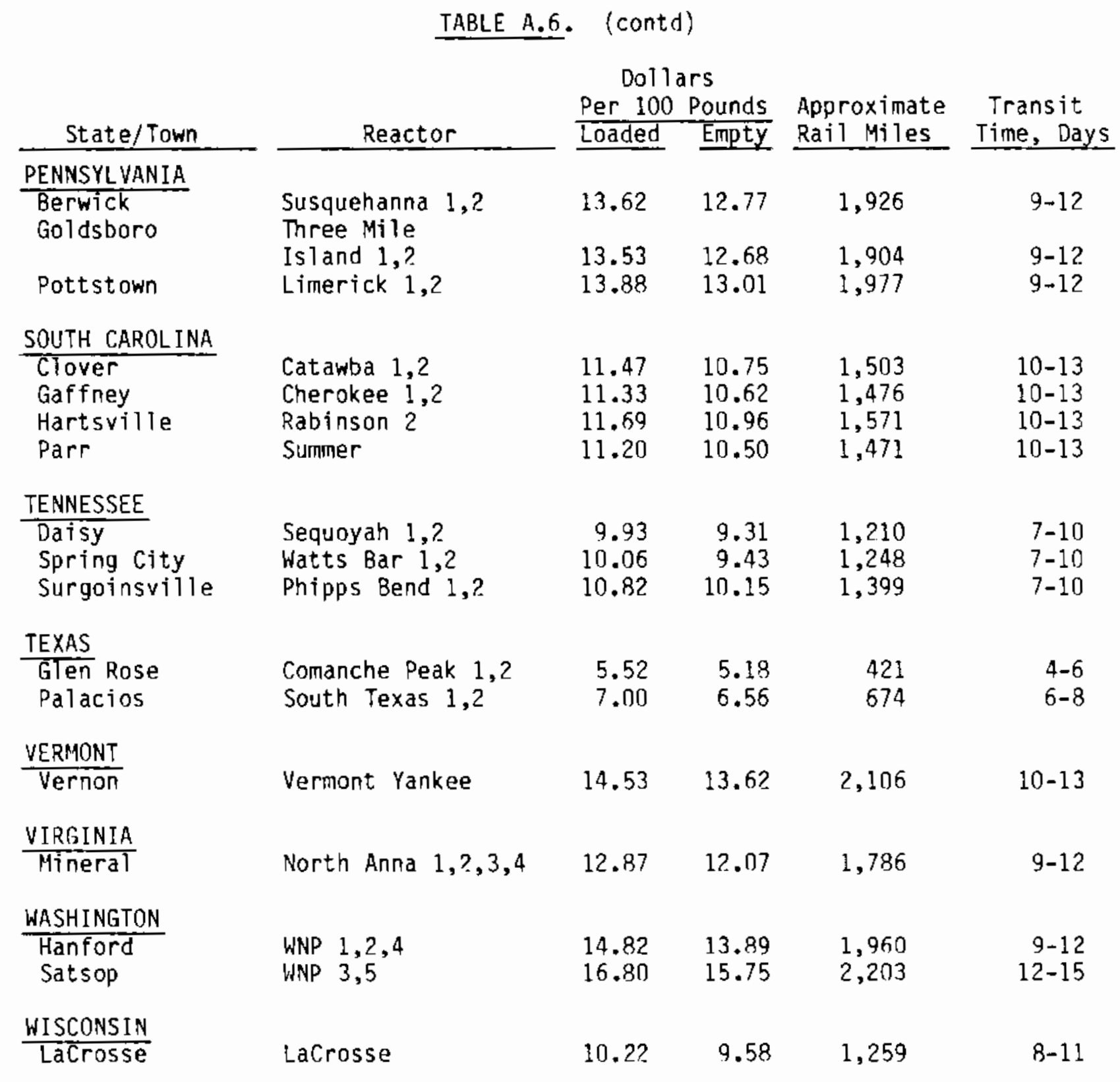


TABLE A.7. Rail General-Freight Shipping Charges, Distances, and Transit Times from LWRs in the Western Region to Western site

Dollars

Per 100 Pounds Approximate Transit

$\frac{\text { State/Town }}{\text { ARIZONA }}$

Reactor Loaded Empty Rail Miles Time, Days

Wintersburg

Palo Verde $1,2,3$

13.69

12.83

1,295

$8-11$

CAL IFORNIA

Clay Station

Rancho Seco

9.10

8.54

926

$5-7$

Eureka

Humboldt Bay

11.00

10.31

1,207

$7-9$

San Clemente

San Onofre $1,2,3$

12.05

11.30

1,185

6-8

OREGON

Ranier

Trojan

5.29

4.96

289

3-5

WASHINGTON

Satsop

WNP 3,5

5.09

4.77

333

4-7 
TABLE A.8. Rail General-Freight Shipping Charges, Distances and Transit Time from LWRs in the Southern Region to Southern Site

Dollars

\begin{tabular}{|c|c|c|c|c|c|}
\hline State/Town & Reactor & $\begin{array}{l}\text { Per } 100 \\
\text { Loaded }\end{array}$ & $\begin{array}{l}\text { Pounds } \\
\text { Empty }\end{array}$ & $\begin{array}{l}\text { Approximate } \\
\text { Rail Miles } \\
\end{array}$ & $\begin{array}{c}\text { Transit } \\
\text { Time, Days } \\
\end{array}$ \\
\hline$\frac{\text { ALABAMA }}{\text { Scottsboro }}$ & Bellefonte 1,2 & 5.25 & 4.92 & 406 & $5-7$ \\
\hline$\frac{\text { ARKANSAS }}{\text { RusselTville }}$ & Arkansas Nuclear 1,2 & 5.63 & 5.28 & 475 & $5-7$ \\
\hline$\frac{\text { FLORIDA }}{\text { Red Level }}$ & Crystal River 3 & 6.26 & 5.87 & 551 & $7-10$ \\
\hline $\begin{array}{l}\frac{\text { GEORGIA }}{\text { Baxley }} \\
\text { Waynesboro }\end{array}$ & $\begin{array}{l}\text { Hatch } 1,2 \\
\text { Vogt le } 1,2\end{array}$ & $\begin{array}{l}5.98 \\
6.40\end{array}$ & $\begin{array}{l}5.61 \\
6.00\end{array}$ & $\begin{array}{l}508 \\
562\end{array}$ & $\begin{array}{l}6-8 \\
6-8\end{array}$ \\
\hline$\frac{\text { KANSAS }}{\text { Burlington }}$ & Holf Creek & 7.64 & 7.16 & 779 & $7-10$ \\
\hline $\begin{array}{l}\frac{\text { LOUISIANA }}{\text { St. Francisville }} \\
\text { Taft }\end{array}$ & $\begin{array}{l}\text { River Bend } 1 \\
\text { Waterford } 3\end{array}$ & $\begin{array}{l}4.32 \\
4.14\end{array}$ & $\begin{array}{l}4.05 \\
3.89\end{array}$ & $\begin{array}{l}244 \\
235\end{array}$ & $\begin{array}{l}4-6 \\
5-7\end{array}$ \\
\hline$\frac{\text { MISSISSIPPI }}{\text { Iuka }}$ & $\begin{array}{l}\text { Yellow Creek 1,2 } \\
\text { Grand Gulf i,2 }\end{array}$ & $\begin{array}{l}4.73 \\
3.82\end{array}$ & $\begin{array}{l}4.43 \\
3.59\end{array}$ & $\begin{array}{l}301 \\
191\end{array}$ & $\begin{array}{l}5-7 \\
4-6\end{array}$ \\
\hline $\begin{array}{l}\text { NORTH CAROL INA } \\
\text { Cornelius } \\
\text { Newhill } \\
\text { South Port }\end{array}$ & $\begin{array}{l}\text { Mcfuire } 1, ? \\
\text { Harris } 1,2,3,4 \\
\text { Brunswick } 1,2\end{array}$ & $\begin{array}{l}7.15 \\
7.64 \\
7.89\end{array}$ & $\begin{array}{l}6.71 \\
7.16 \\
7.40\end{array}$ & $\begin{array}{l}689 \\
776 \\
824\end{array}$ & $\begin{array}{l}5-7 \\
7-9 \\
7-9\end{array}$ \\
\hline $\begin{array}{l}\text { SOUTH CAROLINA } \\
\text { Clover } \\
\text { Gaffney } \\
\text { Hartsville } \\
\text { Parr }\end{array}$ & $\begin{array}{l}\text { Catawba } 1,2 \\
\text { Cherokee } 1,2 \\
\text { Robinson } 2 \\
\text { Summer }\end{array}$ & $\begin{array}{l}6.92 \\
6.63 \\
7.27 \\
6.63\end{array}$ & $\begin{array}{l}6.49 \\
6.21 \\
6.82 \\
6.21\end{array}$ & $\begin{array}{l}641 \\
614 \\
708 \\
608\end{array}$ & $\begin{array}{l}5-7 \\
5-7 \\
6-8 \\
5-7\end{array}$ \\
\hline $\begin{array}{l}\text { TENNESSEE } \\
\text { Daisy } \\
\text { Spring City } \\
\text { Surgoinsville }\end{array}$ & $\begin{array}{l}\text { Sequoyah } 1, ? \\
\text { Watts Bar } 1,2 \\
\text { Phipps Bend } 1,2\end{array}$ & $\begin{array}{l}5.25 \\
5.42 \\
6.40\end{array}$ & $\begin{array}{l}4.92 \\
5.08 \\
6.00\end{array}$ & $\begin{array}{l}385 \\
419 \\
570\end{array}$ & $\begin{array}{l}4-6 \\
4-6 \\
5-7\end{array}$ \\
\hline $\begin{array}{l}\frac{\text { TEXAS }}{\text { Glen Rose }} \\
\text { Palacios }\end{array}$ & $\begin{array}{l}\text { Comanche Peak 1,2 } \\
\text { South Texas } 1,2\end{array}$ & $\begin{array}{l}6.51 \\
6.63\end{array}$ & $\begin{array}{l}6.10 \\
6.21\end{array}$ & $\begin{array}{l}581 \\
613\end{array}$ & $\begin{array}{l}5-7 \\
5-7\end{array}$ \\
\hline$\frac{\text { VIRGINIA }}{\text { Mineral }}$ & North Anna $1,2,3,4$ & 8.64 & 8.10 & 957 & $9-12$ \\
\hline
\end{tabular}


TABLF A.9. Rail General Freight Shipping Charges, Distances and Transit Times from LWRs in the North Central Region to North Central Site

\begin{tabular}{|c|c|c|c|c|c|}
\hline State/Town & Reactor & $\begin{array}{r}\text { Dol1 } \\
\text { Per } 100 \\
\text { Loaded } \\
\end{array}$ & $\begin{array}{l}\text { Pounds } \\
\text { Empty }\end{array}$ & $\begin{array}{l}\text { Approximate } \\
\text { Rai1 Miles } \\
\end{array}$ & $\begin{array}{l}\text { Transit } \\
\text { Time, Days } \\
\end{array}$ \\
\hline \multicolumn{6}{|l|}{ ILLINOIS } \\
\hline Brajdwood & Braidwood 1,2 & 4.86 & 4.56 & 333 & $3-5$ \\
\hline Byron & Byron 1,2 & 4.32 & 4.05 & 245 & $3-5$ \\
\hline Clinton & Clinton 1 & 5.42 & 5.08 & 419 & $4-6$ \\
\hline Cordova & quad Cities 1,2 & 4.73 & 4.43 & 315 & $4-6$ \\
\hline Morris & Dresden $1,2,3$ & 4.86 & 4.56 & 333 & $3-5$ \\
\hline Seneca & LaSalle County 1,2 & 4.86 & 4.56 & 333 & $3-5$ \\
\hline Zion & Zion 1,2 & 4.58 & 4.30 & 281 & $2-4$ \\
\hline \multicolumn{6}{|l|}{ IOWA } \\
\hline Pa To & Arnold & 4.58 & 4.30 & 292 & $4-6$ \\
\hline \multicolumn{6}{|l|}{ MINNESOTA } \\
\hline MonticeTlo & Monticello & 3.47 & 3.25 & 160 & $3-5$ \\
\hline Red Wing & Prairie Island 1,2 & 2.70 & 2.54 & 78 & $3-5$ \\
\hline \multicolumn{6}{|l|}{ MISSOURI } \\
\hline Futton & Callaway 1,2 & 6.14 & 5.75 & 539 & $5-7$ \\
\hline \multicolumn{6}{|l|}{ NEBRASKA } \\
\hline Brownvil1e & Cooper & 5.77 & 5.41 & 479 & $5-7$ \\
\hline Ft. Calhoun & Ft. Calhoun 1 & 5.42 & 5.08 & 407 & $4-6$ \\
\hline \multicolumn{6}{|l|}{ WISCONSIN } \\
\hline$\overline{\text { LaCrosse }}$ & LaCrosse & 3.03 & 2.84 & 109 & $3-5$ \\
\hline
\end{tabular}


TABLE A.10. Rail General-Freight Shipping Charges, Distances, Transit Times

from LWRs in the Northeastern Region to Northeastern Site

\begin{tabular}{|c|c|c|c|c|c|}
\hline State/Town & Reactor & $\begin{array}{r}\text { Dol } 1 \\
\text { Per } 100 \\
\text { Lodded } \\
\end{array}$ & $\begin{array}{l}\text { rs } \\
\text { Pounds } \\
\text { Empty }\end{array}$ & $\begin{array}{l}\text { Approximate } \\
\text { Rail Miles } \\
\end{array}$ & $\begin{array}{l}\text { Transit } \\
\text { Time, Days } \\
\end{array}$ \\
\hline \multicolumn{6}{|l|}{ CONNECTICUT } \\
\hline Waterford & Millstone $1,2,3$ & 7.24 & 6.78 & 629 & $7-10$ \\
\hline \multicolumn{6}{|l|}{ INDIANA } \\
\hline Madison & Marble Hill 1,2 & 5.48 & 5.14 & 380 & $3-5$ \\
\hline \multicolumn{6}{|l|}{ MAINE } \\
\hline Wiscasset & Maine Yankee & 8.32 & 7.80 & 783 & $7-10$ \\
\hline \multicolumn{6}{|l|}{ MICHIGAN } \\
\hline Bridgman & Cook 1,? & 5.35 & 5.02 & 346 & $4-6$ \\
\hline Midland & Midl and 1,2 & 5.06 & 4.74 & 308 & $4-6$ \\
\hline Newport & Fermi 2 & 4.08 & 3.83 & 197 & $3-5$ \\
\hline \multicolumn{6}{|l|}{ NEW HAMPSHIRE } \\
\hline Seabrook & Seabrook $1, ?$ & 7.49 & 7.02 & 673 & $7-10$ \\
\hline \multicolumn{6}{|l|}{ NEW YORK } \\
\hline$\overline{\text { Scriba }}$ & $\begin{array}{l}\text { Nine-Mile Point } 1,2 \\
\text { Fitzpatrick }\end{array}$ & 5.06 & 4.74 & 315 & $3-5$ \\
\hline \multicolumn{6}{|l|}{$\mathrm{OHIO}$} \\
\hline $\begin{array}{l}\text { North Perry } \\
\text { Oak Harbor }\end{array}$ & $\begin{array}{l}\text { Perry } 1,2 \\
\text { Davis-Besse } 1\end{array}$ & $\begin{array}{l}2.73 \\
3.43\end{array}$ & $\begin{array}{l}2.56 \\
3.22\end{array}$ & $\begin{array}{r}65 \\
126\end{array}$ & $\begin{array}{l}2-3 \\
2-3\end{array}$ \\
\hline \multicolumn{6}{|l|}{ PENNSYLVANIA } \\
\hline Berwick & Susquehanna $1, ?$ & 5.20 & 4.88 & 323 & $3-5$ \\
\hline Goldsboro & Three-Mile Island 1,2 & 5.06 & 4.74 & 312 & $3-5$ \\
\hline Pottstown & Limerick 1,2 & 5.62 & 5.27 & 396 & $3-6$ \\
\hline \multicolumn{6}{|l|}{ VERMONT } \\
\hline Vernon & Vermont Yankee & 6.57 & 6.16 & 540 & $5-7$ \\
\hline
\end{tabular}


TABLE A.11. Average Rail Transit Speed

\begin{tabular}{l} 
Total Distance \\
Traveled, Miles \\
\hline $0-300$ \\
$301-1100$ \\
$1101-1900$ \\
$1901-2400$
\end{tabular}

General Freight Transit Speed, Miles/Day

47

88

143

182 
APPENDIX B

ACTIVITY LIMITS FOR HIGHWAY ROUTE CONTROLLED QUANTITIES 
ACTIVITY LIMITS FOR HIGHWAY ROUTE CONTROLLED QUANTITIES

IABLE B.1. Activity Limits for Highway Route Controlled Quantities (All values in curies [Ci])

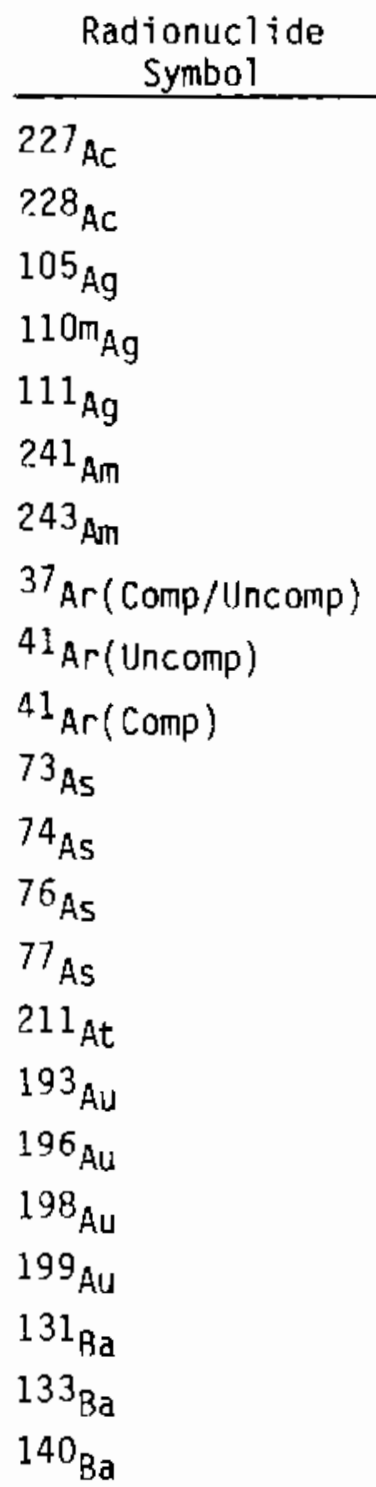

\begin{tabular}{|c|c|}
\hline $\begin{array}{l}\text { Normal } \\
\text { Form a) }\end{array}$ & $\begin{array}{l}\text { Specj a } \\
\text { Form }\end{array}$ \\
\hline 9 & $30 K$ \\
\hline $12 \mathrm{~K}$ & $30 K$ \\
\hline $30 \mathrm{~K}$ & $30 K$ \\
\hline $21 \mathrm{~K}$ & $21 \mathrm{~K}$ \\
\hline $30 \mathrm{~K}$ & $30 \mathrm{~K}$ \\
\hline 24 & $24 \mathrm{~K}$ \\
\hline 24 & $24 K$ \\
\hline $30 \mathrm{~K}$ & $30 \mathrm{~K}$ \\
\hline $30 \mathrm{~K}$ & $30 \mathrm{~K}$ \\
\hline $3 K$ & $3 K$ \\
\hline $30 \mathrm{~K}$ & $30 \mathrm{~K}$ \\
\hline $30 \mathrm{~K}$ & $30 K$ \\
\hline $30 K$ & $30 K$ \\
\hline $30 \mathrm{~K}$ & $30 \mathrm{~K}$ \\
\hline $21 K$ & $30 \mathrm{~K}$ \\
\hline $30 \mathrm{~K}$ & $30 K$ \\
\hline $30 \mathrm{~K}$ & $30 \mathrm{~K}$ \\
\hline $30 \mathrm{~K}$ & $30 \mathrm{~K}$ \\
\hline $30 \mathrm{~K}$ & $30 \mathrm{~K}$ \\
\hline $30 K$ & $30 K$ \\
\hline $30 \mathrm{~K}$ & $30 \mathrm{~K}$ \\
\hline $30 \mathrm{~K}$ & $30 \mathrm{~K}$ \\
\hline
\end{tabular}

(a) As defined in 10 CFR 73 but special form is considered to be nondisposable by virtue of monolithic form or high integrity encapsulation. 
TABLE B.1. (contd)

\begin{tabular}{|c|c|c|}
\hline $\begin{array}{c}\text { Radionuclide } \\
\text { Symbol } \\
\end{array}$ & $\begin{array}{l}\text { Normal } \\
\text { Form (a) }\end{array}$ & $\begin{array}{l}\text { Specja) } \\
\text { Form }\end{array}$ \\
\hline${ }^{7} \mathrm{Be}$ & $30 \mathrm{~K}$ & $30 \mathrm{~K}$ \\
\hline $206_{B i}$ & $15 \mathrm{~K}$ & $15 \mathrm{~K}$ \\
\hline${ }^{207} \mathrm{Bi}$ & $30 \mathrm{~K}$ & $30 \mathrm{~K}$ \\
\hline $210_{\mathrm{Bi}}(\mathrm{RaE})$ & $12 \mathrm{~K}$ & $30 \mathrm{~K}$ \\
\hline $212_{B i}$ & $18 \mathrm{~K}$ & $18 \mathrm{~K}$ \\
\hline${ }^{249_{B K}}$ & $3 K$ & $30 \mathrm{~K}$ \\
\hline $77_{\mathrm{Br}}$ & $30 \mathrm{~K}$ & $30 \mathrm{~K}$ \\
\hline $82_{\mathrm{Br}}$ & $18 \mathrm{~K}$ & $18 \mathrm{~K}$ \\
\hline${ }^{11} \mathrm{C}$ & $30 \mathrm{~K}$ & $30 \mathrm{~K}$ \\
\hline${ }^{14} \mathrm{C}$ & $30 \mathrm{~K}$ & $30 \mathrm{~K}$ \\
\hline${ }^{45} \mathrm{Ca}$ & $30 K$ & $30 \mathrm{~K}$ \\
\hline${ }^{47} \mathrm{Ca}$ & $30 K$ & $30 \mathrm{~K}$ \\
\hline${ }^{109} \mathrm{Cd}$ & $30 k$ & $30 \mathrm{~K}$ \\
\hline $115 m_{C d}$ & $30 K$ & $30 \mathrm{~K}$ \\
\hline${ }^{115^{C} \mathrm{Cd}}$ & $30 \mathrm{~K}$ & $30 \mathrm{~K}$ \\
\hline${ }^{139} \mathrm{Ce}$ & $30 \mathrm{~K}$ & $30 \mathrm{~K}$ \\
\hline${ }^{141} \mathrm{Ce}$ & $30 K$ & $30 \mathrm{~K}$ \\
\hline${ }^{143} \mathrm{Ce}$ & $30 \mathrm{~K}$ & $30 \mathrm{~K}$ \\
\hline${ }^{144} \mathrm{Ce}$ & $21 k$ & $30 \mathrm{~K}$ \\
\hline${ }^{249} \mathrm{Cf}$ & 6 & $6 K$ \\
\hline${ }^{250} \mathrm{Cf}$ & 21 & $21 k$ \\
\hline${ }^{252} \mathrm{Cf}$ & 27 & $6 K$ \\
\hline${ }^{36} \mathrm{Cl}$ & $30 \mathrm{~K}$ & $30 \mathrm{~K}$ \\
\hline${ }^{38} \mathrm{Cl}$ & $30 \mathrm{~K}$ & $30 k$ \\
\hline${ }^{242} \mathrm{Cm}$ & 600 & $30 \mathrm{~K}$ \\
\hline${ }^{243} \mathrm{~cm}$ & 27 & $27 k$ \\
\hline${ }^{244} \mathrm{Cm}$ & 30 & $30 K$ \\
\hline${ }^{245} \mathrm{Cm}$ & 18 & $18 \mathrm{~K}$ \\
\hline
\end{tabular}

(a) As defined in 10 CFR 73 but special form is considered to be nondisposable by virtue of monolithic form or high integrity encapsulation. 
TABLE B.1. (contd)

\begin{tabular}{|c|c|c|}
\hline $\begin{array}{c}\text { Radionuclide } \\
\text { Symbol }\end{array}$ & $\begin{array}{l}\text { Normal } \\
\text { Form }\end{array}$ & $\begin{array}{l}\text { Specja } \\
\text { Form }(a)\end{array}$ \\
\hline${ }^{246} \mathrm{~cm}$ & 18 & $18 \mathrm{~K}$ \\
\hline${ }^{56} \mathrm{Co}$ & $15 K$ & $15 K$ \\
\hline${ }^{57} \mathrm{Co}$ & $30 \mathrm{~K}$ & $30 \mathrm{~K}$ \\
\hline${ }^{58 \mathrm{~m}} \mathrm{Co}$ & $30 \mathrm{~K}$ & $30 K$ \\
\hline${ }^{58} \mathrm{Co}$ & $30 \mathrm{~K}$ & $30 K$ \\
\hline${ }^{60} \mathrm{Co}$ & $21 k$ & $21 k$ \\
\hline${ }^{51} \mathrm{Cr}$ & $30 \mathrm{~K}$ & $30 K$ \\
\hline${ }^{129} \mathrm{Cs}$ & $30 \mathrm{~K}$ & $30 K$ \\
\hline${ }^{131} \mathrm{Cs}$ & $30 \mathrm{~K}$ & $30 K$ \\
\hline $134 \pi \mathrm{cs}$ & $30 \mathrm{~K}$ & $30 \mathrm{~K}$ \\
\hline${ }^{134} \mathrm{Cs}$ & $30 K$ & $30 K$ \\
\hline${ }^{135} \mathrm{Cs}$ & $30 \mathrm{~K}$ & $30 \mathrm{~K}$ \\
\hline${ }^{136} \mathrm{Cs}$ & $21 \mathrm{k}$ & $21 \mathrm{~K}$ \\
\hline${ }^{137} \mathrm{Cs}$ & $30 \mathrm{~K}$ & $30 K$ \\
\hline${ }^{64} \mathrm{Cu}$ & $30 \mathrm{~K}$ & $30 K$ \\
\hline${ }^{67} \mathrm{Cu}$ & $30 \mathrm{~K}$ & $30 K$ \\
\hline${ }^{165} 0 y$ & $30 \mathrm{~K}$ & $30 \mathrm{~K}$ \\
\hline 166 Dy & $30 \mathrm{~K}$ & $30 \mathrm{~K}$ \\
\hline${ }^{169} \mathrm{Er}$ & $30 K$ & $30 K$ \\
\hline $171_{\mathrm{Er}}$ & $30 \mathrm{~K}$ & $30 K$ \\
\hline${ }^{152 m} \mathrm{Er}$ & $30 \mathrm{~K}$ & $30 \mathrm{~K}$ \\
\hline${ }^{152} \mathrm{Er}$ & $30 \mathrm{~K}$ & $30 K$ \\
\hline${ }^{154} \mathrm{Er}$ & $15 \mathrm{~K}$ & $30 \mathrm{~K}$ \\
\hline${ }^{155} \mathrm{Er}$ & $30 \mathrm{~K}$ & $30 \mathrm{~K}$ \\
\hline $18_{F}$ & $30 \mathrm{~K}$ & $30 K$ \\
\hline${ }^{52} \mathrm{Fe}$ & $15 \mathrm{~K}$ & $15 \mathrm{~K}$ \\
\hline${ }^{55} \mathrm{Fe}$ & $30 \mathrm{~K}$ & $30 \mathrm{~K}$ \\
\hline${ }^{59} \mathrm{Fe}$ & $30 \mathrm{~K}$ & $30 \mathrm{~K}$ \\
\hline
\end{tabular}

(a) As defined in 10 CFR 73 but special form is considered to be nondisposable by virtue of monolithic form or high integrity encapsulation. 
TABLE B.1. (contd)

\begin{tabular}{|c|c|c|}
\hline $\begin{array}{c}\text { Radionucl ide } \\
\text { Symbol }\end{array}$ & $\begin{array}{l}\text { Normal } \\
\text { Form }\end{array}$ & $\begin{array}{l}\text { Specjal } \\
\text { Form }\end{array}$ \\
\hline${ }^{67} \mathrm{Ga}$ & $30 \mathrm{~K}$ & $30 \mathrm{~K}$ \\
\hline${ }^{68} \mathrm{Ga}$ & $30 \mathrm{~K}$ & $30 \mathrm{~K}$ \\
\hline${ }^{72} \mathrm{Ga}$ & $21 \mathrm{~K}$ & $21 \mathrm{~K}$ \\
\hline${ }^{153_{\mathrm{Gd}}}$ & $30 \mathrm{~K}$ & $30 K$ \\
\hline${ }^{159} \mathrm{Gd}$ & $30 \mathrm{~K}$ & $30 \mathrm{~K}$ \\
\hline $68_{\mathrm{Ge}}$ & $30 \mathrm{~K}$ & $30 K$ \\
\hline $71_{\mathrm{Ge}}$ & $30 \mathrm{~K}$ & $30 \mathrm{~K}$ \\
\hline${ }^{3} \mathrm{H}$ & $\dagger$ & $\dagger$ \\
\hline $181_{\mathrm{Hf}}$ & $30 \mathrm{~K}$ & $30 \mathrm{~K}$ \\
\hline $197 \mathrm{~m}_{\mathrm{Hg}}$ & $30 \mathrm{~K}$ & $30 \mathrm{~K}$ \\
\hline${ }^{197} \mathrm{Hg}$ & $30 \mathrm{~K}$ & $30 \mathrm{~K}$ \\
\hline${ }^{203} \mathrm{Hg}$ & $30 \mathrm{~K}$ & $30 \mathrm{~K}$ \\
\hline $156_{\mathrm{Ho}}$ & $30 \mathrm{~K}$ & $30 \mathrm{~K}$ \\
\hline${ }^{123} \mathrm{I}$ & $30 \mathrm{~K}$ & $30 \mathrm{~K}$ \\
\hline $125_{I}$ & $30 \mathrm{~K}$ & $30 K$ \\
\hline${ }^{126} \mathrm{I}$ & $30 \mathrm{~K}$ & $30 \mathrm{~K}$ \\
\hline${ }^{129} \mathrm{I}$ & $6 \mathrm{~K}$ & $30 \mathrm{~K}$ \\
\hline${ }^{131} \mathrm{I}$ & $30 \mathrm{~K}$ & $30 x$ \\
\hline $132_{I}$ & $2.1 \mathrm{~K}$ & $21 k$ \\
\hline $133_{1}$ & $30 \mathrm{~K}$ & $30 \mathrm{~K}$ \\
\hline${ }^{134}{ }_{I}$ & $24 \mathrm{~K}$ & $24 K$ \\
\hline${ }^{135} \mathrm{I}$ & $30 \mathrm{~K}$ & $30 \mathrm{~K}$ \\
\hline 111 In & $30 \mathrm{~K}$ & $30 \mathrm{~K}$ \\
\hline${ }^{113 m}$ In & $30 \mathrm{~K}$ & $30 \mathrm{~K}$ \\
\hline $114 m_{I n}$ & $30 \mathrm{~K}$ & $30 \mathrm{~K}$ \\
\hline $115 \mathrm{~m}$ In & $30 \mathrm{~K}$ & $30 \mathrm{~K}$ \\
\hline${ }^{190} \mathrm{Ir}$ & $30 \mathrm{~K}$ & $30 \mathrm{~K}$ \\
\hline
\end{tabular}

(a) As defined in 10 CFR 73 but special form is considered to be nondisposable by virtue of monolithic form or high integrity encapsulation. 
TABLE B.1. (contd)

\begin{tabular}{|c|c|c|}
\hline $\begin{array}{c}\text { Radionuclide } \\
\text { Symbol }\end{array}$ & $\begin{array}{l}\text { Norma? } \\
\text { Form (a) }\end{array}$ & $\begin{array}{l}\text { Specjal } \\
\text { Form }\end{array}$ \\
\hline${ }^{192} \mathrm{Ir}$ & $30 \mathrm{~K}$ & $30 \mathrm{~K}$ \\
\hline${ }^{194} \mathrm{Ir}$ & $30 \mathrm{~K}$ & $30 \mathrm{~K}$ \\
\hline $42_{k}$ & $30 \mathrm{~K}$ & $30 \mathrm{~K}$ \\
\hline $43_{k}$ & $30 k$ & $30 K$ \\
\hline $85 m_{K r}$ (Uncomp) & $30 \mathrm{~K}$ & $30 K$ \\
\hline $85 m_{k r}$ (Comp) & $9 \mathrm{~K}$ & $9 K$ \\
\hline $85_{k r}$ (Uncomp $)$ & $30 \mathrm{~K}$ & $30 K$ \\
\hline $85_{\mathrm{Kr}}$ (Comp) & $15 K$ & $15 K$ \\
\hline${ }^{B 7} \mathrm{Kr}$ (Uncomp) & $30 K$ & $30 \mathrm{~K}$ \\
\hline${ }^{87} \mathrm{Kr}$ (Comp) & 1800 & 1800 \\
\hline $140 \mathrm{La}$ & $30 \mathrm{~K}$ & $30 K$ \\
\hline $177 \mathrm{Lu}$ & $30 \mathrm{~K}$ & $30 K$ \\
\hline MFP & 1200 & $30 \mathrm{~K}$ \\
\hline $28 \mathrm{Mg}$ & $18 \mathrm{~K}$ & $18 \mathrm{~K}$ \\
\hline $52 \mathrm{Mn}$ & $15 K$ & $15 K$ \\
\hline $54_{M n}$ & $30 \mathrm{~K}$ & $30 \mathrm{~K}$ \\
\hline $56 \mathrm{Mn}$ & $15 K$ & $15 K$ \\
\hline $99 \mathrm{MO}_{\mathrm{O}}$ & $30 \mathrm{~K}$ & $30 \mathrm{~K}$ \\
\hline $13_{\mathrm{N}}$ & $30 \mathrm{~K}$ & $30 \mathrm{~K}$ \\
\hline${ }^{22} \mathrm{Na}$ & $24 K$ & $24 K$ \\
\hline${ }^{24} \mathrm{Na}$ & $15 K$ & $15 K$ \\
\hline $93 \mathrm{~m}_{\mathrm{Nb}}$ & $30 \mathrm{~K}$ & $30 \mathrm{~K}$ \\
\hline${ }^{95} \mathrm{Nb}$ & $30 \mathrm{~K}$ & $30 K$ \\
\hline${ }^{97}{ }_{N b}$ & $30 \mathrm{~K}$ & $30 \mathrm{~K}$ \\
\hline${ }^{147} \mathrm{Nd}$ & $30 K$ & $30 \mathrm{~K}$ \\
\hline${ }^{149} \mathrm{Nd}$ & $30 k$ & $30 K$ \\
\hline${ }^{59} \mathrm{Ni}$ & $30 K$ & $30 \mathrm{~K}$ \\
\hline
\end{tabular}

(a) As defined in 10 CFR 73 but special form is considered to be nondisposable by virtue of monolithic form or high integrity encapsulation. 
TABLE B.1. (contd)

\begin{tabular}{|c|c|c|}
\hline $\begin{array}{c}\text { Radi onuelide } \\
\text { Symbol }\end{array}$ & $\begin{array}{l}\text { Norma! } \\
\text { Form }(\mathrm{a})\end{array}$ & $\begin{array}{l}\text { Specja } \\
\text { Form }\end{array}$ \\
\hline${ }^{63} \mathrm{Ni}$ & $30 K$ & $30 \mathrm{~K}$ \\
\hline $65 \mathrm{Ni}$ & $30 K$ & $30 K$ \\
\hline${ }^{237} \mathrm{~Np}$ & 15 & $15 \mathrm{~K}$ \\
\hline${ }^{239} \mathrm{~Np}$ & $30 \mathrm{~K}$ & $30 \mathrm{~K}$ \\
\hline $185_{0 \mathrm{~s}}$ & $30 \mathrm{~K}$ & $30 \mathrm{~K}$ \\
\hline${ }^{191_{0 \mathrm{~S}}}$ & $30 \mathrm{~K}$ & $30 K$ \\
\hline $191 \mathrm{~m}$ os & $30 \mathrm{~K}$ & $30 \mathrm{~K}$ \\
\hline${ }^{193} 0 \mathrm{~s}$ & $30 K$ & $30 \mathrm{~K}$ \\
\hline $32 p$ & $30 K$ & $30 \mathrm{~K}$ \\
\hline $230 \mathrm{~Pa}$ & 2400 & $30 \mathrm{~K}$ \\
\hline $231 \mathrm{~Pa}$ & 6 & $6 \mathrm{~K}$ \\
\hline${ }^{233} \mathrm{~Pa}$ & $30 \mathrm{~K}$ & $30 K$ \\
\hline $201_{\mathrm{Pb}}$ & $30 \mathrm{~K}$ & $30 K$ \\
\hline $210_{\mathrm{Pb}}$ & 600 & $30 \mathrm{~K}$ \\
\hline $212 \mathrm{pb}$ & $18 \mathrm{~K}$ & $18 \mathrm{~K}$ \\
\hline${ }^{103} \mathrm{pd}$ & $30 K$ & $30 K$ \\
\hline${ }^{109} \mathrm{Pd}$ & $30 \mathrm{~K}$ & $30 \mathrm{~K}$ \\
\hline${ }^{147} \mathrm{Pm}$ & $30 \mathrm{~K}$ & $30 \mathrm{~K}$ \\
\hline${ }^{149} \mathrm{Pm}$ & $30 \mathrm{~K}$ & $30 x$ \\
\hline${ }^{210} \mathrm{Po}_{0}$ & 600 & $30 K$ \\
\hline $142 \mathrm{pr}$ & $30 \mathrm{~K}$ & $30 \mathrm{~K}$ \\
\hline${ }^{143} \mathrm{Pr}$ & $30 \mathrm{~K}$ & $30 K$ \\
\hline${ }^{191} \mathrm{pt}$ & $30 K$ & $30 \mathrm{~K}$ \\
\hline $193 \mathrm{mpt}$ & $30 K$ & $30 \mathrm{~K}$ \\
\hline${ }^{197 \pi} \mathrm{mt}$ & $30 K$ & $30 \mathrm{~K}$ \\
\hline${ }^{197} \mathrm{Pt}$ & $30 K$ & $30 K$ \\
\hline $238 \mathrm{Pu}$ & 9 & $9 K$ \\
\hline${ }^{239} \mathrm{Pu}$ & 6 & $6 K$ \\
\hline
\end{tabular}

(a) As defined in 10 CFR 73 but special form is considered to be nondisposable by virtue of monolithic form or high integrity encapsulation. 
TARLE B.1. (contd)

\begin{tabular}{|c|c|c|}
\hline $\begin{array}{c}\text { Radi onuclide } \\
\text { Symbol }\end{array}$ & $\begin{array}{l}\text { Normal } \\
\text { Form a) }\end{array}$ & $\begin{array}{l}\text { Specja) } \\
\text { Form }\end{array}$ \\
\hline $240 \mathrm{pu}$ & 6 & $6 K$ \\
\hline${ }^{24} 1_{P_{u}}$ & 300 & $30 K$ \\
\hline${ }^{242} \mathrm{pu}$ & 9 & $9 K$ \\
\hline $223_{\mathrm{Ra}}$ & 600 & $30 K$ \\
\hline${ }^{224} \mathrm{Ra}$ & 1500 & $18 \mathrm{~K}$ \\
\hline $226_{\mathrm{Ra}}$ & 150 & $30 K$ \\
\hline $228_{\mathrm{Ra}}$ & 150 & $30 K$ \\
\hline${ }^{81} 1_{\mathrm{Rb}}$ & $30 K$ & $30 \mathrm{~K}$ \\
\hline${ }^{86} \mathrm{Rb}$ & $30 \mathrm{~K}$ & $30 K$ \\
\hline${ }^{87} \mathrm{Rb}$ & $30 K$ & $30 \mathrm{~K}$ \\
\hline $\mathrm{Rb}(\mathrm{Nat})$ & $30 \mathrm{~K}$ & $30 K$ \\
\hline${ }^{186} \mathrm{Re}$ & $30 K$ & $30 \mathrm{~K}$ \\
\hline${ }^{187} \mathrm{Re}$ & $30 K$ & $30 K$ \\
\hline${ }^{188} \mathrm{Re}$ & $30 \mathrm{~K}$ & $30 \mathrm{~K}$ \\
\hline $\operatorname{Re}(\mathrm{Nat})$ & $30 K$ & $30 K$ \\
\hline $103 m_{\mathrm{Rh}}$ & $30 K$ & $30 \mathrm{~K}$ \\
\hline $105_{\mathrm{Rh}}$ & $30 \mathrm{~K}$ & $30 \mathrm{~K}$ \\
\hline $222_{R n}$ & $6 \mathrm{~K}$ & $30 K$ \\
\hline $97 \mathrm{Ru}$ & $30 K$ & $30 K$ \\
\hline${ }^{103} \mathrm{Ru}$ & $30 \mathrm{~K}$ & $30 \mathrm{~K}$ \\
\hline${ }^{105_{\mathrm{Ru}}}$ & $30 \mathrm{~K}$ & $30 \mathrm{~K}$ \\
\hline${ }^{106_{\mathrm{Ru}}}$ & $21 k$ & $30 K$ \\
\hline${ }^{35} \mathrm{~S}$ & $30 K$ & $30 \mathrm{~K}$ \\
\hline${ }^{122} \mathrm{Sb}$ & $30 K$ & $30 \mathrm{~K}$ \\
\hline $124 \mathrm{Sb}$ & $15 K$ & $15 K$ \\
\hline${ }^{125} \mathrm{Sb}$ & $30 K$ & $30 K$ \\
\hline${ }^{46} \mathrm{Sc}$ & $24 K$ & $24 K$ \\
\hline${ }^{47} \mathrm{Sc}$ & $30 \mathrm{~K}$ & $30 \mathrm{~K}$ \\
\hline
\end{tabular}

(a) As defined in 10 CFR 73 but special form is considered to be nondisposable by virtue of monolithic form or high integrity encapsulation. 
TABLE B.1. (contd)

\begin{tabular}{|c|c|c|}
\hline $\begin{array}{l}\text { Radionucl ide } \\
\text { Symbol }\end{array}$ & $\begin{array}{l}\text { Normal } \\
\text { Form (a) } \\
\end{array}$ & $\begin{array}{l}\text { Spec }[a] \\
\text { Form }\end{array}$ \\
\hline${ }^{48} \mathrm{sc}$ & $15 \mathrm{~K}$ & $15 K$ \\
\hline${ }^{75} \mathrm{se}$ & $30 k$ & $30 k$ \\
\hline${ }^{31} \mathrm{Si}$ & $30 K$ & $30 k$ \\
\hline${ }^{147} \mathrm{Sm}$ & $30 K$ & $30 k$ \\
\hline${ }^{151} \mathrm{Sm}$ & $30 \mathrm{~K}$ & $30 K$ \\
\hline${ }^{153} \sin$ & $30 k$ & $30 k$ \\
\hline${ }^{113} \mathrm{Sn}$ & $30 K$ & $30 \mathrm{~K}$ \\
\hline $119 m_{S n}$ & $30 \mathrm{~K}$ & $30 \mathrm{~K}$ \\
\hline${ }^{125} \mathrm{Sn}$ & $30 K$ & $30 \mathrm{~K}$ \\
\hline${ }^{85 m} \mathrm{sr}$ & $30 K$ & $30 K$ \\
\hline${ }^{85} \mathrm{Sr}$ & $30 \mathrm{~K}$ & $30 \mathrm{~K}$ \\
\hline${ }^{87} \mathrm{~m} \mathrm{Sr}$ & $30 \mathrm{~K}$ & $30 \mathrm{~K}$ \\
\hline${ }^{89} \mathrm{Sr}$ & $30 \mathrm{~K}$ & $30 K$ \\
\hline${ }^{90} \mathrm{Sr}$ & 1200 & $30 K$ \\
\hline${ }^{91} \mathrm{Sr}$ & $30 \mathrm{~K}$ & $30 k$ \\
\hline${ }^{92} \mathrm{Sr}$ & $30 k$ & $30 k$ \\
\hline$T($ Uncomp $)$ & $30 K$ & $30 K$ \\
\hline$T$ (Comp) & $30 K$ & $30 K$ \\
\hline $\begin{array}{l}T \text { (Actuated Tuminous } \\
\text { paint) }\end{array}$ & $30 K$ & $30 K$ \\
\hline $\begin{array}{l}T(\text { Absorbed on } \\
\text { sotid) }\end{array}$ & $30 \mathrm{~K}$ & $30 \mathrm{~K}$ \\
\hline $\mathrm{T}$ (Tritiated water) & $30 K$ & $30 \mathrm{~K}$ \\
\hline$T$ (other forms) & $30 k$ & $30 K$ \\
\hline${ }^{182} \mathrm{Ta}$ & $30 \mathrm{~K}$ & $30 k$ \\
\hline${ }^{160} \mathrm{~Tb}$ & $30 K$ & $30 \mathrm{~K}$ \\
\hline${ }^{96 \mathrm{~m}} \mathrm{Tc}$ & $30 \mathrm{~K}$ & $30 \mathrm{~K}$ \\
\hline${ }^{96} \mathrm{TC}$ & $18 \mathrm{~K}$ & $18 \mathrm{~K}$ \\
\hline
\end{tabular}

(a) As defined in 10 CFR 73 but special form is considered to be nondisposable by virtue of monolithic form or high integrity encapsulation. 
TABLE B.1. (contd)

\begin{tabular}{|c|c|c|}
\hline $\begin{array}{c}\text { Radionuclide } \\
\text { Symbol }\end{array}$ & $\begin{array}{l}\text { Normal } \\
\text { Form }(a) \\
\end{array}$ & $\begin{array}{l}\text { Specja } \\
\text { Form }\end{array}$ \\
\hline${ }^{97 m} \mathrm{Tc}$ & $30 \mathrm{~K}$ & $30 \mathrm{~K}$ \\
\hline${ }^{97} \mathrm{TC}$ & $30 \mathrm{~K}$ & $30 K$ \\
\hline${ }^{99 m} \mathrm{TC}$ & $30 k$ & $30 k$ \\
\hline${ }^{99} \mathrm{Tc}$ & $30 \mathrm{~K}$ & $30 \mathrm{~K}$ \\
\hline${ }^{125 \mathrm{~m}} \mathrm{Te}$ & $30 \mathrm{~K}$ & $30 \mathrm{~K}$ \\
\hline${ }^{127 m_{\mathrm{Te}}}$ & $30 \mathrm{~K}$ & $30 \mathrm{~K}$ \\
\hline${ }^{127} \mathrm{Te}$ & $30 \mathrm{~K}$ & $30 \mathrm{~K}$ \\
\hline${ }^{129 m_{T e}}$ & $30 \mathrm{~K}$ & $30 \mathrm{~K}$ \\
\hline${ }^{129} \mathrm{Te}$ & $30 k$ & $30 \mathrm{~K}$ \\
\hline $131 m_{T e}$ & $30 K$ & $30 k$ \\
\hline${ }^{132} \mathrm{Te}$ & $21 \mathrm{~K}$ & $21 \mathrm{~K}$ \\
\hline${ }^{227} \mathrm{Th}$ & 600 & $30 k$ \\
\hline${ }^{228} \mathrm{Th}$ & 24 & $18 \mathrm{~K}$ \\
\hline${ }^{230} \mathrm{Th}$ & 9 & $9 \mathrm{~K}$ \\
\hline${ }^{231} \mathrm{Th}$ & $30 \mathrm{~K}$ & $30 K$ \\
\hline${ }^{232} \mathrm{Th}$ & $30 k$ & $30 \mathrm{~K}$ \\
\hline${ }^{234} \mathrm{Th}$ & $30 \mathrm{~K}$ & $30 K$ \\
\hline Th(Nat) & $30 \mathrm{~K}$ & $30 K$ \\
\hline Th(Irrad) & $30 \mathrm{~K}$ & $30 \mathrm{~K}$ \\
\hline${ }^{200} \mathrm{Tl}$ & $30 \mathrm{~K}$ & $30 \mathrm{~K}$ \\
\hline $201 \mathrm{Tl}$ & $30 \mathrm{~K}$ & $30 \mathrm{~K}$ \\
\hline${ }^{202} \mathrm{Tl}$ & $30 \mathrm{~K}$ & $30 K$ \\
\hline${ }^{204} \mathrm{Tl}$ & $30 \mathrm{~K}$ & $30 K$ \\
\hline${ }^{170} \mathrm{Tm}$ & $30 \mathrm{~K}$ & $30 \mathrm{~K}$ \\
\hline${ }^{171_{\mathrm{Tm}}}$ & $30 \mathrm{~K}$ & $30 \mathrm{~K}$ \\
\hline $230_{U}$ & 300 & $30 K$ \\
\hline $232_{U}$ & 90 & $30 \mathrm{~K}$ \\
\hline $233_{y}$ & 300 & $30 k$ \\
\hline
\end{tabular}

(a) As defined in 10 CFR 73 but special form is considered to be nondisposable by virtue of monolithic form or high integrity encapsulation. 
TABLE B.1. (contd)

\begin{tabular}{|c|c|c|}
\hline $\begin{array}{c}\text { Radionucl ide } \\
\text { Symbol }\end{array}$ & $\begin{array}{l}\text { Normal } \\
\text { Form }(a) \\
\end{array}$ & $\begin{array}{l}\text { Specjaj } \\
\text { Form }\end{array}$ \\
\hline $234 v$ & 300 & $30 \mathrm{~K}$ \\
\hline $235_{\mathrm{v}}$ & 600 & $30 \mathrm{~K}$ \\
\hline $236 u$ & 600 & $30 \mathrm{~K}$ \\
\hline $238_{U}$ & $30 \mathrm{~K}$ & $30 \mathrm{~K}$ \\
\hline$v($ Nat $)$ & $30 \mathrm{~K}$ & $30 K$ \\
\hline$U(E n r<20 \%)$ & $30 \mathrm{~K}$ & $30 K$ \\
\hline$U(E n r>20 \%)$ & 300 & $30 K$ \\
\hline U(Dep1) & $30 \mathrm{~K}$ & $30 \mathrm{~K}$ \\
\hline U(Irrad) & $30 K$ & $30 \mathrm{~K}$ \\
\hline $48 v$ & $18 \mathrm{~K}$ & $18 \mathrm{~K}$ \\
\hline $181_{W}$ & $30 K$ & $30 \mathrm{~K}$ \\
\hline $185_{W}$ & $30 \mathrm{~K}$ & $30 \mathrm{~K}$ \\
\hline $187_{W}$ & $30 \mathrm{~K}$ & $30 \mathrm{~K}$ \\
\hline $127 \times \mathrm{e}$ (IJncomp) & $30 \mathrm{~K}$ & $30 \mathrm{~K}$ \\
\hline $127 \times \mathrm{Xe}$ (Comp) & $15 K$ & $15 K$ \\
\hline $131 m_{x e}$ (Comp) & $30 \mathrm{~K}$ & $30 \mathrm{~K}$ \\
\hline $131 m_{x e}($ Uncomp) & $30 \mathrm{~K}$ & $30 \mathrm{~K}$ \\
\hline $133 \times$ e(IIncomp) & $30 \mathrm{~K}$ & $30 K$ \\
\hline $133 \times$ (Comp) & $15 k$ & $15 \mathrm{~K}$ \\
\hline $135 \times$ Xe (Incomp) & $30 \mathrm{~K}$ & $30 K$ \\
\hline $135 \times$ x (Comp) & $6 \mathrm{~K}$ & $6 K$ \\
\hline $87 y$ & $30 \mathrm{~K}$ & $30 \mathrm{~K}$ \\
\hline $90_{Y}$ & $30 \mathrm{~K}$ & $30 \mathrm{~K}$ \\
\hline $91 m_{Y}$ & $30 \mathrm{~K}$ & $30 \mathrm{~K}$ \\
\hline${ }^{91} Y$ & $30 \mathrm{~K}$ & $30 \mathrm{~K}$ \\
\hline $92 y$ & $30 \mathrm{~K}$ & $30 \mathrm{~K}$ \\
\hline $93 y$ & $30 \mathrm{~K}$ & $30 \mathrm{~K}$ \\
\hline
\end{tabular}

(a) As defined in 10 CFR 73 but special form is considered to be nondisposable by virtue of monolithic form or high integrity encapsulation. 
TABLE B.1. (contd)

\begin{tabular}{|c|c|c|}
\hline $\begin{array}{c}\text { Radionuclide } \\
\text { Symbol }\end{array}$ & $\begin{array}{l}\text { Normal } \\
\text { Form (a) }\end{array}$ & $\begin{array}{l}\text { Specja } \\
\text { Form } \\
\end{array}$ \\
\hline $169_{\mathrm{Yb}}$ & $30 K$ & $30 \mathrm{~K}$ \\
\hline $175_{\mathrm{Yb}}$ & $30 K$ & $30 K$ \\
\hline${ }^{65} \mathrm{Zn}$ & $30 \mathrm{~K}$ & $30 \mathrm{~K}$ \\
\hline${ }^{69 m} \mathrm{Zn}$ & $30 K$ & $30 \mathrm{~K}$ \\
\hline${ }^{67} \mathrm{Zn}$ & $30 \mathrm{~K}$ & $30 \mathrm{~K}$ \\
\hline${ }^{93} \mathrm{Zr}$ & $30 \mathrm{~K}$ & $30 \mathrm{~K}$ \\
\hline${ }^{95} \mathrm{Zr}$ & $30 \mathrm{~K}$ & $30 \mathrm{~K}$ \\
\hline $97 \mathrm{Zr}$ & $30 \mathrm{~K}$ & $30 \mathrm{~K}$ \\
\hline
\end{tabular}

(a) As defined in 10 CFR 73 but special form is considered to be nondisposable by virtue of monolithic form or high integrity encapsulation. 

No. of

Copies

OFFSITE

J. H. Carlson

U.S. Department of Energy

1000 Independence Avenue, S.W.

Washington, DC 20585

M. D. Connor

U.S. Department of Energy

1000 Independence Avenue, 5.W.

Washington, DC 20585

K. A. Klein

U.S. Department of Energy

1000 Independence Avenue, S.W. Washington, DC 20585

L. Marks

U.S. Department of Energy

1000 Independence Avenue, S.W.

Washington, DC 20585

R. Philpott

U.S. Department of Energy

1000 Independence Avenue, S.W. Washington, D.C. 20585

E. L. Wilmot

U.S. Department of Energy

1000 Independence Avenue, 5.W. Washington, DC 20585

C. Boggs-Mayes

U.S. Department of Energy

Chicago Operations Office

$9800 \mathrm{~S}$. Cass Avenue

Argonne, IL 60439
No. of

Copies

P. N. Gross

Oak Ridge National Laboratory

P.0. Box $X$

Oak Ridge, TN 37830

M. A. Heiskell

Dak Ridge National Laboratory

P.0. Box $X$

Oak Ridge, TN 37830

L. Shappert

Oak Ridge National Laboratory

P. 0. Box $X$

Oak Ridge, TN 37830

J. W. Cashwel1

Sandia National Laboratories

P.0. Box 5800

Albuquerque, NM 87185

R. Luna

Sandia National Laboratories

P.0. Box 5800

Albuquerque, NM 87185

5. Gupta

Battelle Columbus Laboratories

OSTP Department

505 King Avenue

Col umbus, $\mathrm{OH} 43201$

R. Peterson

Battelle Columbus Laboratories

OSTP Department

$505 \mathrm{King}$ Avenue

Col umbus, $\mathrm{OH} 43201$ 
No of

Copies

D. Kerr

Battelle Columbus Laboratories

OSTP Department

$505 \mathrm{King}$ Avenue

Columbus, $\mathrm{OH} 43201$

C. Kimm

Battelle Columbus Laboratories

OSTP Department

505 King Avenue

Col umbus, $\mathrm{OH} 43201$

30 DOE Technical Information Center

ONSITE

6 DOE Richland Operations Office

J. Peterson

M. Oayani

R. B. Goranson

R. D. Izatt

D. C. Langstaff

J. J. Sutey
No of

Copies

(5) Rockwell Hanford Operations

E. F. Votaw (5)

47 Pacific Northwest Laboratory

L. L. Clark

B. M. Cole

C. A. Counts

P. M. Daling

R. L. Engel

J. F. Fletcher

G. M. Holter

C. J. Hostick

C. H. Imhoff

T. L. Lotz

P. N. McDuffie

R. W. McKee

G. H. McNair (20)

D. F. Newman

K. J. Schneider

M. R. Shay

S. M. Short

M. B. Triplett

R. C. Walling

M. K. White

T. W. Wood

Publishing Coordination (2)

Technical Information (MH) (5) 